\title{
Diversity and Biogeography of the Scleractinian Coral Fauna of Easter Island (Rapa Nui) ${ }^{1}$
}

\author{
Peter W. Glynn, ${ }^{2}$ Gerard M. Wellington, ${ }^{3}$ Bernhard Riegl, ${ }^{4}$ Donald B. Olson, ${ }^{5}$ Eric Borneman,${ }^{3}$ \\ and Evie A. Wieters 6
}

\begin{abstract}
Three surveys at Easter Island (Rapa Nui) spanning the period 19992005 , and examination of private and museum collections, have revealed a depauperate zooxanthellate scleractinian fauna. Collections were all made off island shelf exposures, from tide pools to $70 \mathrm{~m}$ with scuba, and by dredging to $100 \mathrm{~m}$. With synonymies, reassignments, and two new records in the families Pocilloporidae and Faviidae, the Easter Island coral fauna now comprises 13 species. Pocilloporid and poritid coral abundances were generally high on all island shelves protected from southern swells. A cluster analysis of the coral fauna relationships of 19 south, central, and far-eastern Pacific sites indicates a strong affinity between those of Easter Island and the far-eastern Pacific equatorial region (e.g., Colombia, Ecuador, Panamá, and the Galápagos Islands). The precipitous drop in coral species richness from the Pitcairn Island group (61 species) to Easter Island suggests the presence of a dispersal barrier between these two remote southeastern Pacific areas, separated by $\sim 1,800 \mathrm{~km}$ of deep ocean waters. Consideration of the surface circulation based on satellite-tracked surface drifters confirms this conclusion. Surface currents are from east to west along the topography on which Easter and Sala-y-Gómez Islands sit, suggesting a substantial barrier to recruitment from the west.
\end{abstract}

\begin{abstract}
${ }^{1}$ Support was provided by National Geographic Society grant 6047-97 to G.M.W., National Science Foundation grants OCE-0002317 to P.W.G., OCE-0036525000 to R. Dunbar and G.M.W., OCE-0119976 to D.B.O., NSF GRFP to E.B., and NOAA grant NA16OA1443 to B.R. Manuscript accepted 19 April 2006.

${ }^{2}$ Division of Marine Biology and Fisheries, Rosenstiel School of Marine and Atmospheric Science, University of Miami, 4600 Rickenbacker Causeway, Miami, Florida 33149-1098 (e-mail: pglynn@rsmas.miami.edu).

${ }^{3}$ Department of Biology and Biochemistry, University of Houston, Houston, Texas 77204-5513.

${ }^{4}$ National Coral Reef Institute, Oceanographic Center, Nova Southeast University, 8000 North Ocean Drive, Dania, Florida 33004.

${ }^{5}$ Division of Meteorology and Physical Oceanography, Rosenstiel School of Marine and Atmospheric Science, University of Miami, 4600 Rickenbacker Causeway, Miami, Florida 33149-1098.

${ }^{6}$ Departamento de Ecología, Facultad de Ciencias Biológicas, Pontificia Universidad Católica de Chile, Santiago, Chile.
\end{abstract}

Pacific Science (2007), vol. 61, no. 1:67-90

(C) 2007 by University of Hawai'i Press

All rights reserved
LOCATED AT THE southeasternmost apex of the Indo-West Pacific biogeographic realm, Easter (Rapa Nui) and Sala-y-Gómez Islands have commanded special interest in terms of their extreme isolation and biotic affinities with surrounding areas. Easter Island lies about $1,800 \mathrm{~km}$ east of the center of the Pitcairn Island group, and 3,900 and 4,500 km from the Galápagos Islands and the Ecuadorean mainland, respectively (Figure 1). Attracting particular attention has been the high degree of endemism demonstrated by several shallow-occurring marine invertebrate and fish taxa. The few species of corals (Glynn et al. 2003) and mollusks (Rehder 1980) collected at Sala-y-Gómez Island suggest a close relationship with those of Easter Island, but further analysis must await more comprehensive collections. The high level of endemism at Easter Island, ranging from 2 to $39 \%$ in all reasonably well-studied taxa (Randall 1976, Boyko 2003), has prompted the recognition of a Rapanuian Province (Schilder 1965, Rehder 1980). In this study we focus on the scleractinian reef-building 


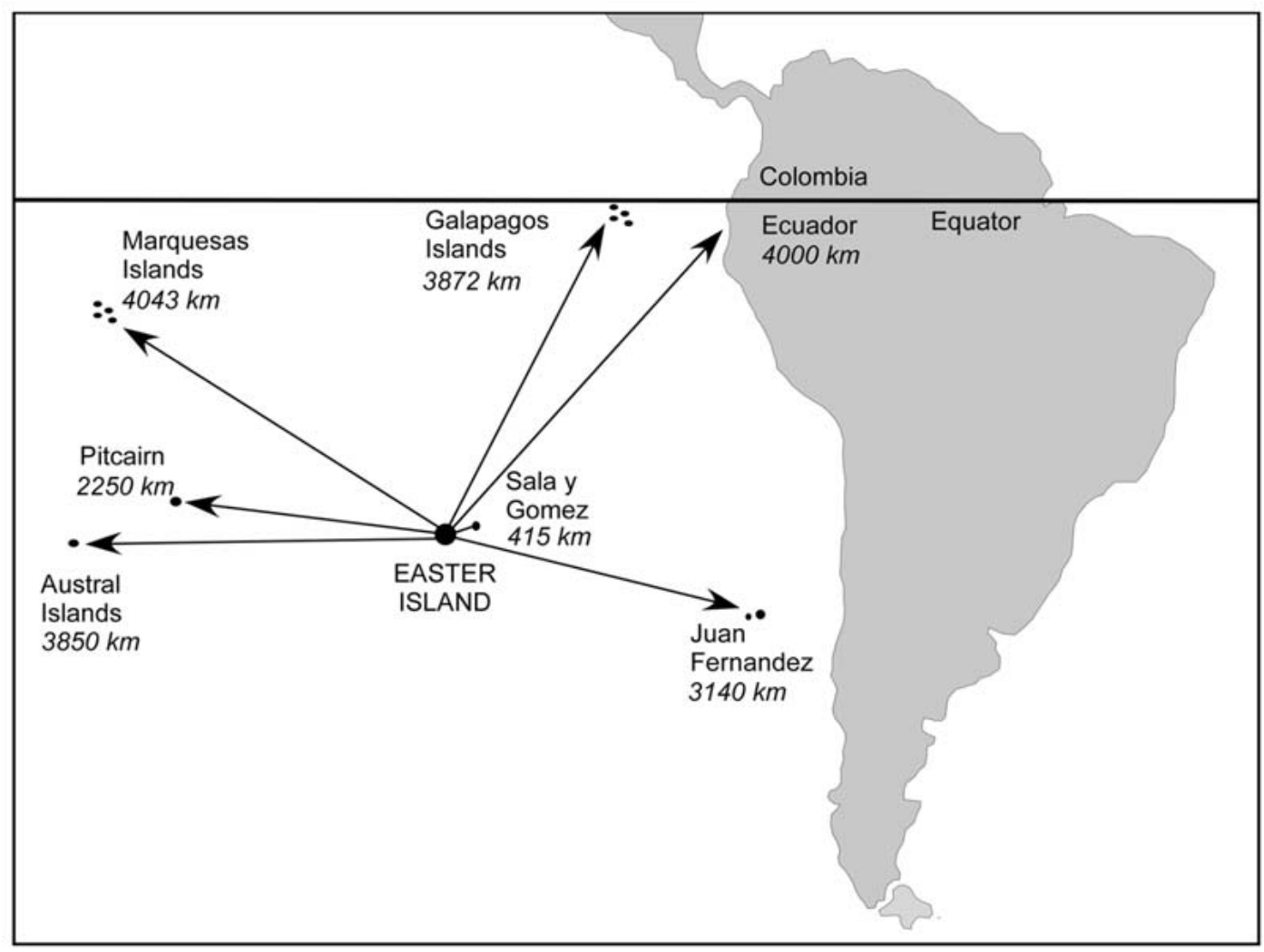

Figure 1. General setting of Easter Island and distances to nearest islands and south American coast with abundant corals (modified after Bahn and Flenley 1992).

(zooxanthellate) coral fauna of Easter Island, its species composition, and its relationship to those of the Pitcairn Island group, other central Pacific areas, and the far-eastern tropical Pacific region. The nature of ocean circulation in the proximity of the proposed province is considered as one clue to its origin. Of interest is the geometry of the subtropical gyre and local topographic-induced features in the flow.

In spite of the relative proximity of the Pitcairn Island group to Easter Island, a general west-to-east surface flow at their latitudinal position $\left(24-28^{\circ} \mathrm{S}\right)$, and the expected structure of the South Pacific subtropical gyre (Wyrtki 1975), there exists a substantial difference in coral species richness (Paulay 1989, Glynn et al. 2003). The Pitcairn group has nearly five times as many species and sev- eral prominent genera (e.g., Acropora, Montipora, Pavona) that are absent from Easter Island (Paulay 1989). Contours of coral generic and species diversity denote, respectively, 20 and 50 for the Pitcairn Island group and 5 and 10 for Easter Island (Veron 1995). Most workers have assumed that the impoverished Easter Island coral fauna was probably most closely allied to that of the Southeast Pacific region (Veron 1995, Paulay 1997). However in apparent contrast, the high proportion of species shared with the far eastern Pacific also suggests a strong link across the eastern Pacific barrier (Wells 1983, Reyes-Bonilla 2002).

The first report of zooxanthellate corals from Easter Island was by Vaughan (1906), who described two species collected during the Albatross Expedition to the eastern tropi- 
cal Pacific. The number of species then increased to six, seven, and then eight from collections examined by Wells $(1972,1983)$ and DiSalvo et al. (1988). More recently 11 species were reported by Glynn et al. (2003). From continuing intensive ecological studies, it is now evident that abundant coral populations are widespread and incipient structural reef development occurs in some areas (Glynn et al. 2003, Hubbard and Garcia 2003).

In the current work the species distribution is used to infer the axes of spread of corals in the Southeast Pacific and therefore the connectivity between the reefs of interest (Roberts 1997, Cowen et al. 2000). A forthcoming study (D.B.O., P.W.G., and B.R., unpubl. data) will demonstrate the existence of surface currents in the subtropical gyre that are unfavorable for transporting planktonic reproductive propagules from the Pitcairn to the Rapanuian island groups. A schematic of the conclusions of that study is included here to link the conclusions based on the systematics and occurrence results reported here. The aims of this study are (1) to provide a detailed taxonomic analysis of Easter Island zooxanthellate scleractinian corals and (2) to describe the biogeographic linkages in relation to known surface current patterns.

\section{Geological Setting of Sala-y-Gómez, Pitcairn, and Easter Islands}

Easter Island is part of a hot-spot trace that extends from the South American coast as the Nazca Ridge and continues to the East Pacific Rise as the Sala-y-Gómez Ridge (Crough 1983). The current hot spot appears to be near the East Pacific Rise crest (GEBCO 1980) as indicated by a symmetric block of high topography extending both east and west of the ridge. This shallow topography extends nearly to Pitcairn Island. Pitcairn itself is thought to be a hot spot (Crough 1983) with its trace extending to the west. Together then the two hot spots create a ridge of high bottom topography along approximately $26^{\circ} \mathrm{S}$. The extension of the raised topography to the east extends all the way to the Peru coast. To the north of the re- gion, the Galápagos Rise and the East Pacific Rise provide similar east-west and northsouth connections as seen in surface-drifter trajectories (D.B.O. et al., unpubl. data). Interaction between ocean currents and this topography is an important facet of the possible connectivity between Easter Island coral populations and those to the west.

\section{General Character of Coral Communities}

Recent quantitative surveys have revealed high zooxanthellate coral abundances at most island sampling sites and substantial framework development in a few areas. Hubbard and Garcia (2003) found coral communities to be best developed along Easter Island's western and northern coasts but much restricted to absent on the southeastern coast. Those workers concluded that frequent exposure to wind waves and ground swells originating near the Antarctic interfered with the settlement and growth of corals along the southeastern coast.

Coral cover is relatively low at shallow depths $(3-7 \mathrm{~m})$ on the western and northern coastal exposures. However, coral abundance often increases rapidly at $8-10 \mathrm{~m}$ and remains high to about $50 \mathrm{~m}$ depth (Glynn et al. 2003, Hubbard and Garcia 2003). The dominant species are Porites lobata and Pocillopora verru$\cos a$, with the former often attaining large colony sizes (1-3 m diameter) compared with the latter $(10-30 \mathrm{~cm}$ diameter). Porites typically makes up the bulk of live coral cover, often contributing from $40 \%$ to sometimes $100 \%$ total community cover. Other coral species are sometimes locally abundant (e.g., Pocillopora damicornis, Pocillopora danae, and Psammocora stellata), but most of the 10 shallow-occurring species are often widely scattered among the community dominants. Three additional species, Leptoseris scabra, Leptoseris solida, and Cycloseris vaughani, are seldom found above $60 \mathrm{~m}$ depth. It is probable that these species are abundant in some deep areas, but their distributions are currently unknown.

Rock and sand, microfilamentous and macroalgae, and crustose coralline algae make up most of the remainder of the substrate. A va- 
riety of invertebrate taxa nestles among the corals and algae, including sponges, bivalves, gastropods, holothurians, ophiuroids, sea urchins, and hermit crabs. Sea urchins, notably Diadema paucispinum; macroalgae (e.g., Lobophora, Sargassum); and herbivorous fishes (Kyphosus bigibbus, Acanthurus leucopareius, and Stegastes fasciolatus) can reach high abundances in some areas, with their occurrences varying both spatially and temporally (DiSalvo et al. 1988, Hubbard and Garcia 2003).

Following the criteria of Hubbard and Garcia (2003) — namely, coral reefs are topographic structures formed by multiple generations of coral growth-structural reefs do exist in some areas. Although these reefs do not reach sea level they are not simple veneers over antecedent platforms. In some instances they attain 2 to $5 \mathrm{~m}$ in vertical relief (Glynn et al. 2003). Such structures were present on the protected northeastern and midwestern coasts of Easter Island, at depths of 15-30 m (Hubbard and Garcia 2003). Porites lobata is the predominant frame-building species.

\section{MATERIALS AND METHODS}

The focus of this study is Easter Island (Rapa Nui), centered at $109^{\circ} 22^{\prime} \mathrm{W}, 27^{\circ} 07^{\prime} \mathrm{S}$. This is one of the most isolated localities in the tropical/subtropical oceans (Figure 1). Coral collection sites were concentrated along the western and northern shores, with some collections also carried out at two offshore islets to the south of the island and at Punta Redonda on the southeastern coast (Figure 2). Most collections were made with scuba to 70 $m$ depth on surveys conducted during 14-19 March 1999, 18-22 March 2000, and 12-20 March 2005. Most illustrated specimens were deposited in the Marine Invertebrate Museum of the Rosenstiel School of Marine

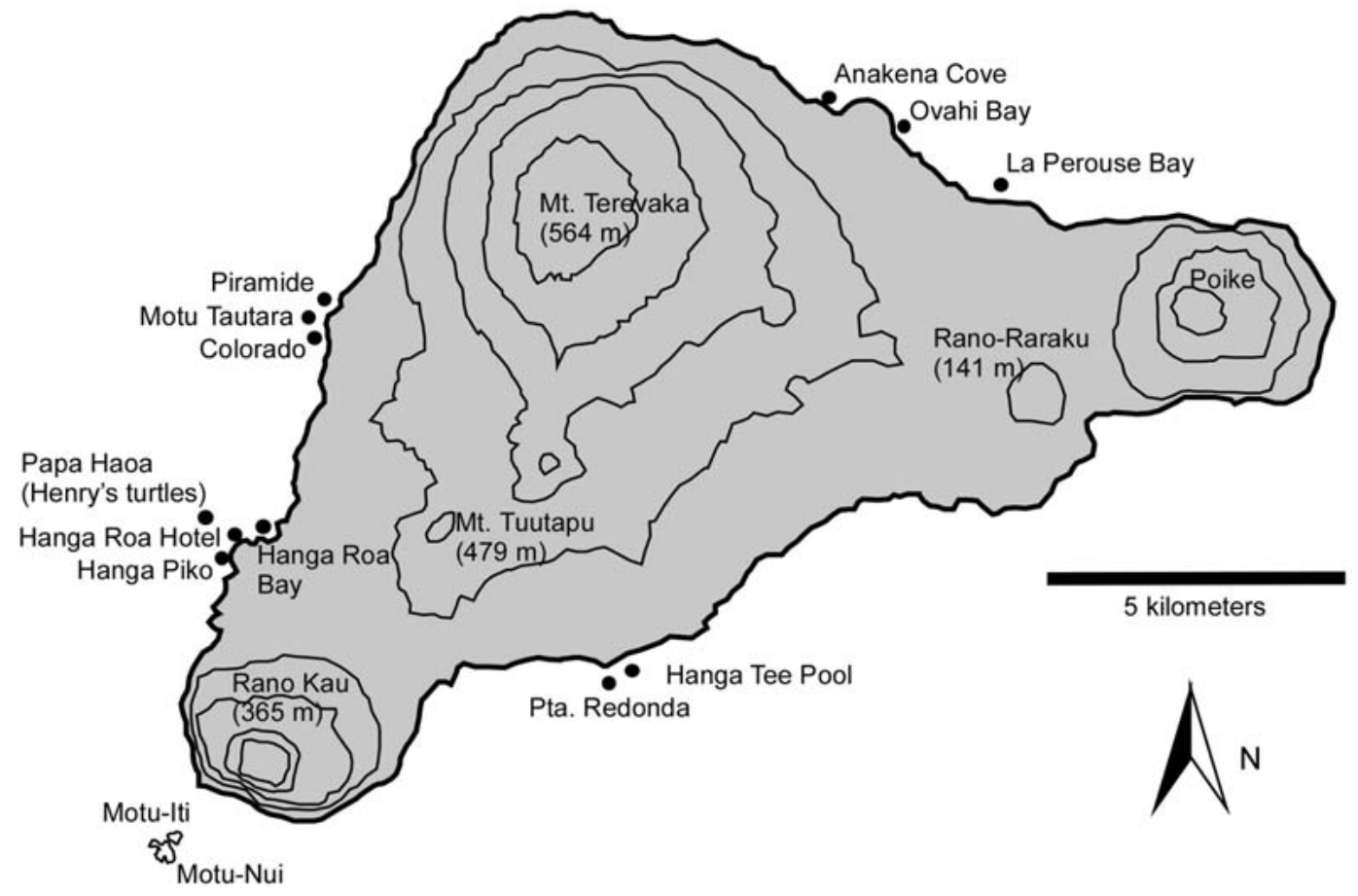

Figure 2. Easter Island with study and collection sites. 
and Atmospheric Science, University of Miami (UMmL). Material was also examined from drag hauls at $100 \mathrm{~m}$, and in the collections of the Museo de Zoología, Departamento de Zoología, Universidad de Concepción (ucmz). This study documents all of the known zooxanthellate scleractinian species from Easter Island with collection information and annotated notes on abundances, colony morphology, and skeletal structure (Appendix 1). The classification of suborders and family assignments follow Veron (1995).

\section{Statistical Analysis of Regional Species Data}

We constructed a biogeographic data set for the region consisting of presence/absence information for coral species from the literature and our own data (see Appendix 2), which included the eastern Pacific coral faunas and others that we thought might serve as source faunas or show some other affinity. Sites included the Society, Tuamotu, Austral, Gambier, and Marquesas Islands (Pichon 1985 and pers. comm.), Pitcairn Island group (Paulay 1989 and pers. comm.), the main Hawaiian Islands (Maragos 1995, Fenner 2005; E. Brown, pers. comm.), Mexico mainland (Leyte Morales et al. 2001, Reyes-Bonilla 2003), Revillagigedo Islands, Clipperton Atoll (Carricart Ganivet and Reyes-Bonilla 1999), Costa Rica, Cocos Island, Panamá (Holst and Guzmán 1993), Colombia (Zapata and Vargas-Ángel 2003), Malpelo Island (Zapata and Vargas-Ángel 2003), the Galápagos Islands, Ecuador mainland, and Fanning Atoll (-Tabuaeran, Line Islands) from Wells (1983), and Glynn and Ault (2000). We searched for grouping by employing agglomerative, hierarchical cluster analysis. To better evaluate how these groups related to each other, we used indirect gradient analysis (sensu Whittaker 1967 and Jongman et al. 1995) via nonmetric multidimensional scaling (Digby and Kempton 1987, Jongman et al. 1995). Because cluster analysis tends to detect markedly discontinuous data structure but also to obscure continuous structure (Jongman et al. 1995), we used an additional ordination method to examine the same matrix of simi- larity measures (based on the binary BrayCurtis similarity index) for two-dimensional ordination. If the patterns obtained by both analyses are consistent, the resulting groupings are considered plausible. This approach has been used routinely and successfully elsewhere (Field et al. 1982, Agard et al. 1993, Warwick and Clarke 1993, Clarke and Warwick 2001). Analyses were perfomed in Primer-E (Clarke and Gorley 2001).

\section{Regional Current Data}

Near-surface circulation in the Southeast Pacific, in the region encompassing Pitcairn Islands and Easter Island $\left(100-135^{\circ} \mathrm{W}\right.$, $\left.16-36^{\circ} \mathrm{S}\right)$, was examined utilizing Tropical Ocean Global Atmosphere (TOGA) program and World Ocean Circulation Experiment (WOCE) Surface Velocity Program (SVP) drifter data. Mean drifter velocity plots with good geographic coverage were available from 1991 to 2000 (http://woce.nodc.noaa.gov/ wdiu/diu_summaries/svp/index.htm). Niller (2001) provided a complete discussion of the drifter characteristics and the deployments in the Pacific. The surface drifter is a standard unit involving a small surface float with a radio transmitter tied to the ocean currents with a $10-\mathrm{m}$ three-dimensional drogue centered at $15 \mathrm{~m}$ depth. The units are tracked by satellite through the Argos system. The drifters follow the near surface flow within $0.02 \mathrm{~m} / \mathrm{sec}$ for the winds in the region of interest. Details of drifter trajectories used in this study are discussed in Olson et al. (unpubl. data).

RESULTS

\section{The Coral Fauna}

A total of 13 species was found. Species authorities and detailed descriptions of all species can be found in Appendix 1. Six species are in the genus Pocillopora. Pocillopora meandrina is a new record in Glynn et al. (2003), which we here recognize as well. Pocillopora ligulata is a new record revealed in this study. We eliminated the name $P$. elegans in favor of P. verrucosa (see discussion in Appendix 1). 
Morphologic analysis indicated that only a single species of Porites (P. lobata) was present despite the occurrence of several clearly distinct colony morphologies. Calice characteristics were uniform among all specimens. Two species of Leptoseris ( $L$. solida and $L$. scabra) were collected. Leptoseris tubulifera of Glynn et al. (2003) is recognized as a synonym of L. scabra. This species was rare and confined to deep water. Only one species of Psammocora ( $P$. stellata) is tentatively recognized because some taxonomic difficulties remain. Two individuals of a single species of Cycloseris (C. vaughani) were dredged from deep water. Although originally only one species of Leptastrea was recorded, morphological reexamination of additional material leads us to recognize two species (L. transversa and L. purpurea). Leptastrea transversa is a new record for Easter Island.

\section{Surface Currents}

Easter and Pitcairn Islands are situated near the axis of the South Pacific subtropical gyre. This places them under the location of minimum wind stress, with easterly trade winds to their north and westerly winds to the south. Dynamic height contours from historical hydrocast data assembled by Wyrtki (1975) show the gyre center to trend to the southeast, with estimated gyre centers at $21^{\circ} \mathrm{S}$ and $130^{\circ} \mathrm{W}$ and at $28^{\circ} \mathrm{S}$ and $104^{\circ} \mathrm{W}$. The satellite-tracked drifter data provide a multiyear depiction of flow around the islands (Figure 3). The result is generally consistent with Wyrtki's (1975) dynamic height charts with westward flow to the northeast of Easter Island. At the longitude of Pitcairn, however, the westward flow is displaced farther north and the flow field just north of

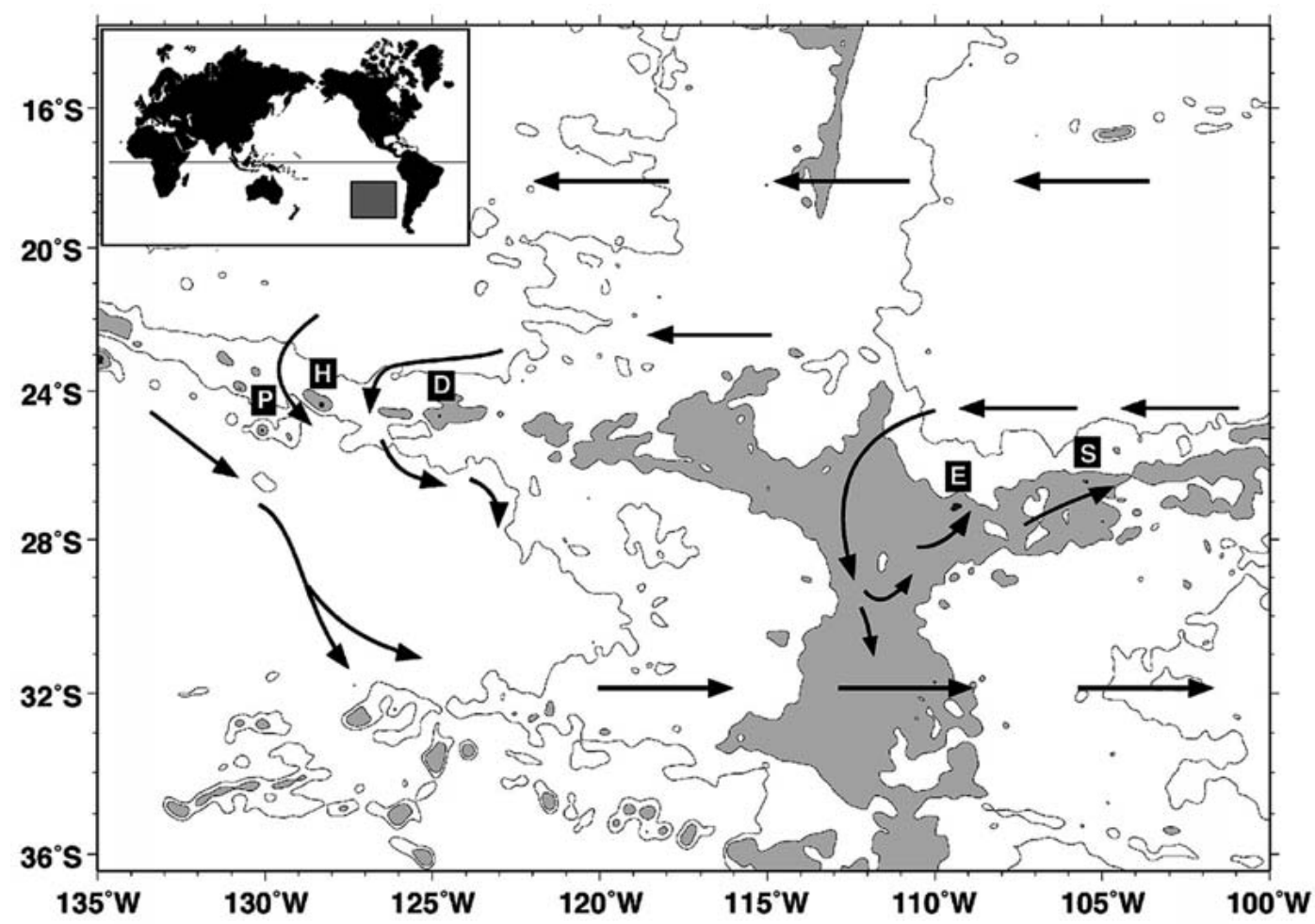

FIgURE 3. Relationship between bottom topography and surface currents in the vicinity of Easter Island and the Pitcairn Island group. Shaded bottom contours $<3,000 \mathrm{~m}$, the next bottom contour is at $5,000 \mathrm{~m}$. E, Easter Island; S, Sala-y-Gómez; D, Ducie; H, Henderson; P, Pitcairn. 
the island is dominated by slow southward drifts. To the southwest of Pitcairn the dominant flow is along the deep topography from the northwest to the southeast. This flow joins a subtropical frontal flow that is found between $29^{\circ}$ and $32^{\circ} \mathrm{S}$. The eastward arrows in Figure $3\left(32^{\circ} \mathrm{S}\right)$ demark the northern edge of this flow. The bulk of this flow may pass through the gap in the topography at $35^{\circ} \mathrm{S}$, $112^{\circ} \mathrm{W}$ just south of the arrows. Some drifters enter this eastward flow from the north, where they execute an anticyclonic turn around the shallow ridge crest to the west of Easter Island. This flow around the shallow topography is an expected result of interactions between the mesoscale eddy field in the ocean and the topography. These in- teractions can totally disrupt the structure of the subtropical gyre circulation (Olson et al., unpubl. data).

\section{Zoogeographic Relationships}

The pattern in the classification and multidimensional scaling ordination suggests the existence of two major faunal groups that further separate into five to six well-defined faunas in the eastern Pacific (Figure 4). A Polynesian/Hawaiian faunal group comprised a central Polynesian fauna, incorporating the Society Islands, Tuamotu, Austral, and Gambier Islands. Also the Pitcairn group and the main Hawaiian Islands were included in this group (largely suggested by the cluster

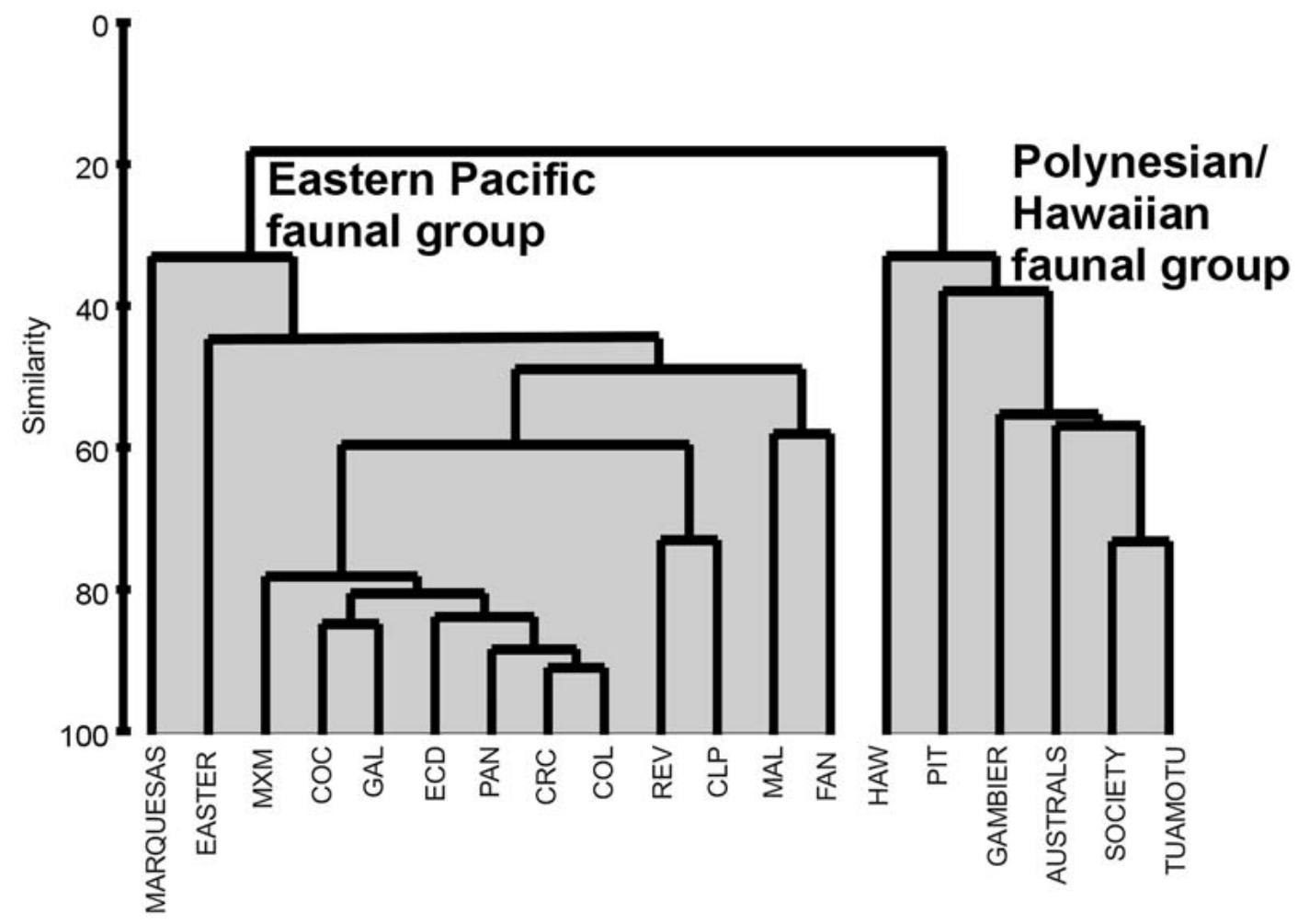

Figure 4. Relationships of faunas between selected central and eastern Pacific faunas that were considered to be important in the context of Easter Island faunas. Dendrogram of an agglomerative, hierarchical cluster analysis using the Bray-Curtis binary similarity index as distance measure and group-average method for cluster formation. MXM, Mexican mainland; COC, Cocos Island, Costa Rica; GAL, Galápagos Islands; ECD, Ecuadorean coast; PAN, Panamá; CRC, Costa Rica; COL, Colombia; REV, Revillagigedo Islands, Mexico; CLP, Clipperton Atoll; MAL, Malpelo Island; FAN, Fanning Atoll (= Tabuaeran); HAW, Hawaiian Islands; PIT, Pitcairn Island. 


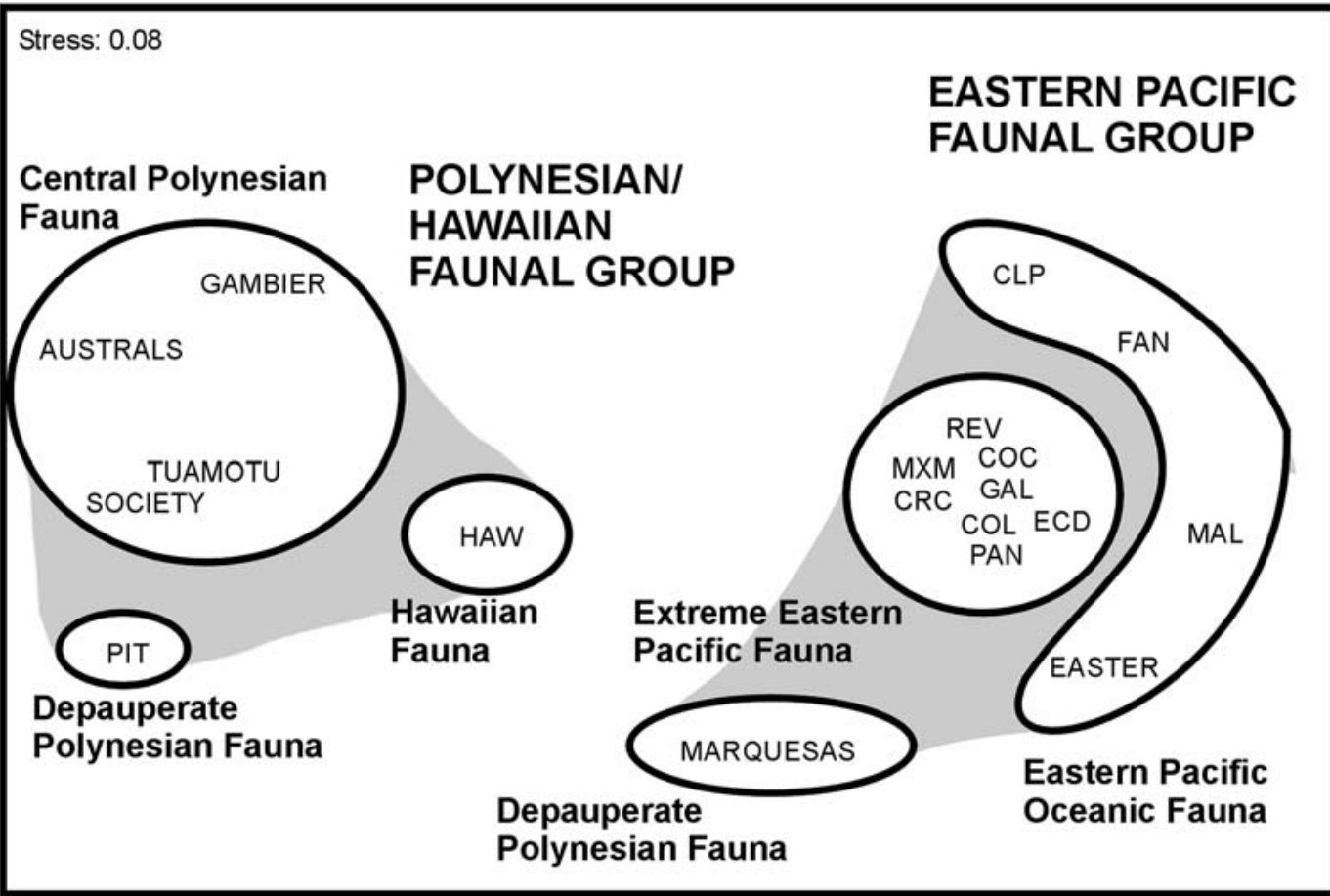

FIgURe 5. Nonmetric multidimensional scaling (MDS) ordination based on the same similarity matrix as Figure 4, showing faunal affinities among Pacific sites.

analysis), even though they were well separated in the ordination. The Pitcairn group was considered a depauparate Polynesian fauna due to the decline in species in comparison with the central Polynesian fauna. The other depauperate Polynesian fauna (Marquesas) was grouped with the Eastern Pacific faunal group. The distance on the plot of these two faunal groups indicates important differences in species composition. The second, but well-separated group consists mostly of eastern Pacific localities. A tight cluster is formed by the faunas of mainland South and Central America (Mexico mainland, Gulf of California, Costa Rica, Panamá, Ecuador, Colombia) and nearby islands (Revillagigedo Archipelago, Cocos Island, and the Galápagos Islands). A somewhat outlying group, which we considered a separate cluster (justified by the weak clustering in the dendrogram and relatively wide separation from the welldefined cluster consisting of the mainland and few island sites), consisted of the oceanic islands Easter, Clipperton, Fanning, and Malpelo. Although distant in the multidimensional scaling plot and clearly an outlier in the classification, the Marquesas Islands were closer to the Eastern Pacific fauna than the Polynesian/Hawaiian faunal group (Figure 5).

\section{DISCUSSION}

The systematic analysis presented here increases the number of recognized zooxanthellate scleractinian corals at Easter Island from 11 (Glynn et al. 2003) to 13 species. Among the six recognized species of Pocillopora, $P$. ligulata is a new record, also previously reported from the far eastern Pacific, Hawai $i$ i, and the South Pacific (Veron 2000). The faviid species Leptastrea transversa is also a new record for Easter Island, known from Hawail $i$ and wide-ranging throughout the 
Indo-Pacific region (Veron 1993, 2000). Extant species of Leptastrea have not been reported from mainland or island localities in the far eastern Pacific (Glynn and Ault 2000, Reyes-Bonilla 2002). Like many other subtropical Indo-Pacific areas at the limits of reef growth, the Easter Island coral fauna comprises the genera Pocillopora, Porites, Psammocora, Leptoseris, and Cycloseris (Veron 1993). It is curious that, although species of Pavona are present at nearly all eastern and southeastern Pacific localities, none was found at Easter Island. Several life history attributes of eastern Pacific Pavona spp. favor longdistance dispersal and presence at remote localities (Glynn and Ault 2000).

Due to the pivotal role of currents as agents of coral dispersal (e.g., Jokiel and Martinelli 1992, Veron 1995), we examined surface circulation patterns in the southeastern Pacific to better understand the possible location of source populations. The Pitcairn Island group and Easter Island are under the influence of the subtropical Southeast Pacific gyre. All surface current plots from 1991 to 2000 showed the influence of this gyre, particularly the westerly movement between $14^{\circ}$ and $20^{\circ} \mathrm{S}$ (Figure 3). Easterly movement of the southern branch of the gyre was also evident between about $28^{\circ}$ and $36^{\circ} \mathrm{S}$, but current directions and velocities were more variable in that region. Maximum South Equatorial Current velocities approached $0.4 \mathrm{~m} \mathrm{sec}^{-1}$ in 1996 and 2000. A notably strong easterly flow occurred in the Pitcairn area between $25^{\circ}$ and $28^{\circ} \mathrm{S}$ in 2000 with maximum velocities in excess of $0.5 \mathrm{~m} \mathrm{sec}^{-1}$. Rapid flow extended to $118^{\circ} \mathrm{W}$, over $14^{\circ}$ of longitude. Mean drifter velocity of four tracts indicated an easterly flow of $29.8 \mathrm{~km}^{\text {day }}{ }^{-1}$. This approximates a travel time of 49 days. Counterclockwise circulation is sometimes evident around Easter Island, which would promote local retention of planktonic propagules in that area. Bearing on this question are the reproductive modes and larval durations; however, little is known of these attributes for Easter Island scleractinians.

The result of this analysis of currents is consistent with the Wyrtki (1975) dynamic height charts, with westward flow to the northeast of Easter Island. At the longitude of Pitcairn, however, the westward flow is displaced farther north and southward drifts dominate the flow field just north of the island. To the southwest of Pitcairn the dominant flow is along the deep topography from the northwest to the southeast. This flow joins a subtropical frontal flow that is found between $29^{\circ}$ and $32^{\circ} \mathrm{S}$. This current passes through a break in the East Pacific Rise at $113^{\circ} \mathrm{W}$. Here some drifters enter this front from a flow that turns anticyclonically around the shallow ridge crest just to the west of Easter Island.

Recruitment of benthic species with planktonic larval stages depends on three factors: (1) the probability of being spawned at a site; (2) the probability of being transported from the spawning site to the habitat where recruitment occurs; and (3) the probability of successful settlement in that habitat (Olson 2006). The final probability of recruitment is then the product of these three probabilities. The flows described previously suggest that although Pitcairn is a possible source of larvae, it is not well connected to Easter Island. In fact Easter is isolated by the topographic flow from most of the Pacific. The only possible connection would be to Sala-y-Gómez Island to its east, which shares the same topographic feature. In this case the topography allows local retention that can play a major role in maintaining the isolated populations (Paris et al. 2002). The faunistic analyses support the oceanographic model and show clearly that the Easter Island fauna has less similarity to that of the Pitcairn group than to that of the far eastern Pacific, indeed suggesting isolation from the west and higher connectivity to the northeast (Figures 4 and $5)$.

The high affinity of Easter Island coral fauna with the far-eastern Pacific coral fauna begs the question of the origin of this close relationship. A chain of relatively shallow seamounts on the Nazca-Sala-y-Gómez Ridge ends in a line eastward (east-northeast) from Easter to near South America (Newman and Foster 1983). Three extant Easter Island coral genera (Porites, Pocillopora, Leptoseris) have been dredged from the "Shoal Guyot" at 
depths of 205-227 m (Allison et al. 1967). This guyot is located $1,500 \mathrm{~km}$ from the Peruvian coast. The Nazca-Sala-y-Gómez line of guyots has existed since the late Oligocene (29 mya) and could have served as steppingstones between Easter Island and the eastern Pacific at various times over this period. Seasurface temperature gradients across the tropical Pacific were not so pronounced as they are today, thus possibly moderating thermal conditions in the southeastern Pacific and allowing the migration of tropical species in this region. Wara et al. (2005) offered evidence for permanent El Niño-like conditions in the eastern tropical Pacific during the early Pliocene, from $\sim 4.5$ to 3.0 mya. It is also possible that current reversals, as occur during present-day El Niño-Southern Oscillation activity, may have been more favorable for west-to-east dispersal events.

\section{ACKNOWLEDGMENTS}

We are especially grateful for the field support offered by Michel and Henri Garcia of the Sociedad de Exploración Marítima Orca, Ltd., Hanga Roa, Isla de Pascua. Also, several specimens in this study were collected and kindly loaned by the Garcias. Thanks are due M. Pichon, H. Reyes-Bonilla, and F. Benzoni for help with species identifications and distribution patterns; J. Artigas, Curator of the Museo de Zoología, Facultad de Ciencias Naturales y Oceanografía, Departamento de Zoología, Universidad de Concepción, Chile, for making his coral collection available for study; and G. Paulay and E. Brown for providing abundance information for corals of the Pitcairn group and the Hawaiian Islands. We thank N. A. Voss for cataloging museum specimens and J. Carpenter for producing graphics. S. Navarrete helped make and source collections in Chile. Species distribution records supplied by an anonymous reviewer and a critique offered by D. K. Hubbard substantially improved this study.

\section{Literature Cited}

Agard, J. B. R., J. Gobin, and R. M. Warwick. 1993. Analysis of marine macrobenthic community structure in relation to pollu- tion, natural oil seepage and seasonal disturbance in a tropical environment (Trinidad, West Indies). Mar. Ecol. Progr. Ser. 92:233-243.

Allison, E. C., J. W. Durham, and L. W. Mintz. 1967. New Southeast Pacific echinoids. Occas. Pap. Calif. Acad. Sci. 62:123.

Bahn, P., and J. Flenley. 1992. Easter Island, earth island. Thames and Hudson, Ltd., London.

Boyko, C. B. 2003. The endemic marine invertebrates of Easter Island: How many species and for how long? Pages 155-175 in J. Loret and J. T. Tanacredi, eds. Easter Island: Scientific exploration into the world's environmental problems in microcosm. Kluwer Academic/Plenum Publishers, New York.

Carricart Ganivet, J. P., and H. Reyes Bonilla. 1999. New and previous records of scleractinian corals from Clipperton Atoll, eastern Pacific. Pac. Sci. 53:370-375.

Clarke, K. R., and R. N. Gorley. 2001. Primer v5: User manual/tutorial. PrimerE, Plymouth, United Kingdom.

Clarke, K. R., and R. M. Warwick. 2001. Change in marine communities: An approach to statistical analysis and interpretation. 2nd ed. Primer-E, Plymouth, United Kingdom.

Cortés, J., and H. M. Guzmán. 1998. Organismos de los arrecifes coralinos de Costa Rica: Descripción, distribución geográfica e historia natural de los corales zooxantelados (Anthozoa: Scleractinia) del Pacífico. Rev. Biol. Trop. 46:55-92.

Cowen, R. K., K. M. M. Lwiza, S. Sponaugle, C. B. Paris, and D. B. Olson. 2000. Connectivity of marine populations: Open or closed? Science (Washington, D.C.) 287:857-859.

Crough, S. T. 1983. Hotspot swells. Annu. Rev. Earth Planet. Sci. 11:165-193.

Digby, P. E., and R. A. Kempton. 1987. Multivariate analysis of ecological communities. Chapman and Hall, London.

DiSalvo, L. H., J. E. Randall, and A. Cea. 1988. Ecological reconnaissance of the Easter Island sublittoral marine environment. Natl. Geogr. Res. 4:451-473.

Fenner, D. 2005. Corals of Hawai'i: A field 
guide to the hard, black and soft corals of Hawai' $i$ and the Northwest Hawaiian Islands, including Midway. Mutual Publishing, Honolulu.

Field, J. G., K. R. Clarke, and R. M. Warwick. 1982. A practical strategy for analysing multispecies distribution patterns. Mar. Ecol. Progr. Ser. 8:37-52.

GEBCO. 1980. General bathymetric chart of the oceans (GEBCO). Plate 5.11. 5th ed. Canadian Hydrographic Service, Ottawa, Canada.

Glynn, P. W., and J. S. Ault. 2000. A biogeographic analysis and review of the far eastern Pacific coral reef region. Coral Reefs 19:1-23.

Glynn, P. W., G. M. Wellington, E. A. Wieters, and S. A. Navarrete. 2003. Reefbuilding coral communities of Easter Island (Rapa Nui), Chile. Pages 473-494 in J. Cortés, ed. Latin American coral reefs. Elsevier, Amsterdam.

Hoffmeister, J. E. 1925. Some corals from American Samoa and the Fiji Islands. Carnegie Inst. Washington Publ., no. 343, Pap. Dep. Mar. Biol. 22:1-90, pl. 1-23.

Holst, I., and H. M. Guzmán. 1993. Lista de corales hermatípicos (Anthozoa: Scleractinia; Hydrozoa: Milleporina) a ambos lados del Istmo de Panamá. Rev. Biol. Trop. 41:871-875.

Hubbard, D. K., and M. Garcia. 2003. The corals and coral reefs of Easter Island-a preliminary look. Pages 53-77 in J. Loret and J. T. Tanacredi, eds. Easter Island: Scientific exploration into the world's environmental problems in microcosm. Kluwer Academic/Plenum Publishers, New York.

Jokiel, P., and F. J. Martinelli. 1992. The vortex model of coral reef biogeography. J. Biogeogr. 19:449-458.

Jongman, R. H. G., C. J. F. ter Braak, and O. F. R. van Tongeren. 1995. Data analysis in community and landscape ecology. Cambridge University Press, Cambridge.

Leyte Morales, G. E., H. Reyes Bonilla, C. E. Cintra Buenrostro, and P. W. Glynn. 2001. Range extension of Leptoseris papyracea (Dana, 1846) to the west coast of Mexico. Bull. Mar. Sci. 69:1233-1237.

Maragos, J. E. 1977. Order Scleractinia:
Stony corals. Pages 158-241 in D. M. Devaney and L. G. Eldredge, eds. Reef and shore fauna of Hawaii, Section I: Protozoa through Ctenophora. Bishop Museum Press, Honolulu.

. 1995. Revised checklist of extant shallow-water stony coral species from Hawaii (Cnidaria: Anthozoa: Scleractinia). Bishop Mus. Occas. Pap. 42:54-55.

Newman, W. A., and B. A. Foster. 1983. The Rapanuian faunal district (Easter and Sala y Gómez): In search of ancient archipelagos. Bull. Mar. Sci. 33:633-644.

Niller, P. P. 2001. The world ocean surface circulation. Pages 193-204 in G. Siedler, J. Church, and J. Gould, eds. Ocean circulation and climate. Academic Press, New York.

Olson, D. B. 2006. Lagrangian biophysical dynamics. In A. Griffa, A. D. Kirwan, A. J. Mariano, T. Özgökmen, and T. Rossby, eds. Lagrangian analysis and prediction of coastal and ocean dynamics. Cambridge University Press, Cambridge.

Paris, C. B., R. K. Cowen, K. M. M. Lwiza, D. P. Wang, and D. B. Olson. 2002. Objective analysis of three-dimensional circulation in the vicinity of Barbados, West Indies: Implication for larval transport. Deep-Sea Res. 49:1571-1590.

Paulay, G. 1989. Marine invertebrates of Pitcairn Island: Species composition and biogeography of corals, mollusks and echinoderms. Atoll Res. Bull. 326:1-28.

- 1997. Diversity and distribution of reef organisms. Pages 298-353 in C. Birkeland, ed. Life and death of coral reefs. Chapman and Hall, New York.

Pichon, M. 1985. Scleractinia. Pages 399-403 in G. Richard, ed. Fauna and flora, a first compendium of French-Polynesian seadwellers. Proc. 5th Int. Coral Reef Congr., Tahiti, Vol. 1. Antenne Museum-Ephe, Moorea, French Polynesia.

Randall, J. E. 1976. The endemic shore fishes of the Hawaiian Islands, Lord Howe Island, and Easter Island. Trav. Doc. ORSTOM 47:49-73.

Rehder, H. A. 1980. The marine mollusks of Easter Island (Isla de Pascua) and Sala y Gómez. Smithson. Contrib. Zool. 289:1167. 
Reyes-Bonilla, H. 2002. Checklist of valid names and synonyms of stony corals (Anthozoa: Scleractinia) from the eastern $\mathrm{Pa}$ cific. J. Nat. Hist. 35:1-13.

. 2003. Coral reefs of the Pacific coast of México. Pages 331-349 in J. Cortés, ed. Latin American coral reefs. Elsevier, Amsterdam.

Riegl, B., and W. E. Piller. 1997. Intracolony variability of calice characteristics in recent Porites lutea Edwards \& Haime, 1916: Implications for fossil identification. Bol. R. Soc. Esp. Hist. Nat. Secc. Geol. 91:305-316.

Roberts, C. M. 1997. Connectivity and management of Caribbean coral reefs. Science (Washington, D.C.) 278:1454-1457.

Schilder, F. A. 1965. The geographical distribution of cowries (Mollusca: Gastropoda). Veliger 7:171-183.

Vaughan, T. W. 1906. Madreporaria. Reports on the scientific results of the expedition to the eastern tropical Pacific in charge of Alexander Agassiz, by the U.S. Fish Commission Steamer "Albatross," from October, 1904 to March, 1905. Bull. Mus. Comp. Zool. Harv. Coll. 50:61-72.

. 1918. Some shoal-water corals from the Murray Islands (Australia), CocosKeeling Islands, and Fanning Island. Carnegie Inst. Washington Publ., no. 213, Pap. Dep. Mar. Biol. 9:49-234.

Veron, J. E. N. 1993. A biogeographic database of hermatypic corals: Species of the central Indo-Pacific, genera of the world. Aust. Inst. Mar. Sci. Monogr. Ser. 10.

. 1995. Corals in space and time: The biogeography and evolution of the Scleractinia. Comstock/Cornell, Ithaca.

. 2000. Corals of the world. Vol. 2. Australian Institute of Marine Science, Townsville.

Veron, J. E. N., and M. Pichon. 1979. Scleractinia of eastern Australia. III. Families Agariciidae, Siderastreidae, Fungiidae, Oculinidae, Merulinidae, Mussidae, Pectiniidae, Caryophylliidae, Dendrophylliidae. Aust. Inst. Mar. Sci. Monogr. Ser. 4.

- 1982. Scleractinia of eastern Australia. Part IV. Family Poritidae. Aust. Inst. Mar. Sci. Monogr. Ser. 5.
Veron, J. E. N., M. Pichon, and M. WijsmanBest. 1977. Scleractinia of eastern Australia. Part II. Families Faviidae, Trachyphyllidae. Aust. Inst. Mar. Sci. Monogr. Ser. 3.

Wara, M. W., A. C. Ravelo, and M. L. Delaney. 2005. Permanent El Niño-like conditions during the Pliocene warm period. Science (Washington, D.C.) 309:758-761.

Warwick, R. M., and K. R. Clarke. 1993. A comparison of methods for analyzing changes in benthic community structure. J. Mar. Biol. Assoc. U.K. 71:225-244.

Wells, J. W. 1972. Notes on Indo-Pacific scleractinian corals. Part 8: Scleractinian corals from Easter Island. Pac. Sci. 26:183-190.

- 1983. Annotated list of the scleractinian corals of the Galápagos. Pages 213-295 in P. W. Glynn and G. M. Wellington, eds. Corals and coral reefs of the Galápagos Islands. University of California Press, Berkeley.

Whittaker, R. H. 1967. Gradient analysis of vegetation. Biol. Rev. 49:207-264.

Wyrtki, K. 1975. Fluctuations of dynamic topography in the Pacific Ocean. J. Phys. Oceanogr. 5:450-459.

Zapata, F. A., and B. Vargas-Ángel. 2003. Corals and coral reefs of the Pacific coast of Colombia. Pages 419-447 in J. Cortés, ed. Latin American coral reefs. Elsevier, Amsterdam.

\section{Appendix 1}

Taxonomic Descriptions of Easter Island Zooxanthellate Coral Species

Phylum CNidaria

Class Anthozoa

Order SCleractinia

Suborder ArchaeocoeniIna

Family Pocilloporidae

Pocillopora verrucosa (Ellis \& Solander, 1786)

Figure $6 A, B$

CORALlum: More openly branching than other Easter Island species, forming fairly open clusters of branches originating from an encrusting to submassive base. Colony diameters $15-25 \mathrm{~cm}$.

BRANCHES: Rounded to slightly oval, diameters 1-3 $\mathrm{cm}$. More irregularly arranged than in other Easter Island species. Branchlets are formed at irregular intervals and positions on the branches, diverging at steep angles (45$\left.90^{\circ}\right)$. 


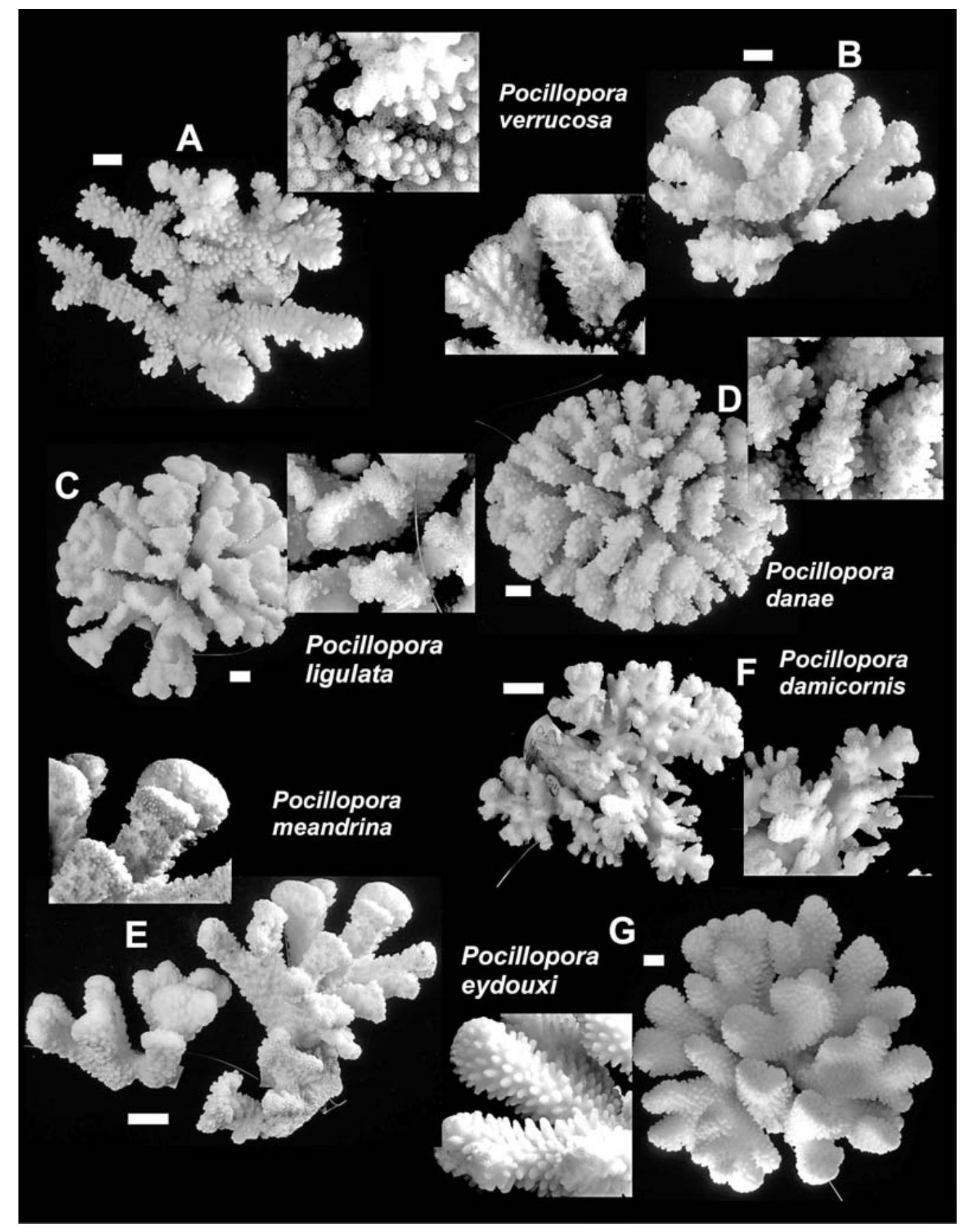

Figure 6. Pocillopora species in the umml collection from Easter Island. Scale bar $=10 \mathrm{~mm}$ with reference to the corallum only. A, B, Pocillopora verrucosa, note irregularly arranged open branches and branchlets arising at various positions along branches; $C, P$. ligulata, branches regularly arranged and round proximally, becoming spatulate and contorted distally; $D, P$. danae, colonies round and symmetrical with compact arrangement of branches; $E, P$. meandrina, branches widely spaced and thick, usually laterally appressed; $F, P$. damicornis, branches thin, irregularly arranged with sharp tips arising from enlarged verrucae; $G, P$. eydouxi, a large robust colony with thick and long branches. 
VERRUCAE: Irregular in size and orientation but always well defined. Smooth appearance, rounded at their apices, usually oriented $60-90^{\circ}$ from their respective branches. Occurring everywhere on branches, including tips, where they become smaller to sometimes barely recognizable.

CORALlites: Uniformly and densely arranged over entire colony but not in rows. Ornamented coenosteal spines surrounding corallites, but spines not always directly attendant to thecae.

SEPTA: Well developed in two cycles $(1 / 8-1 / 4$ corallite radius), frequently with prominent directive septa (up to $1 / 2$ radius). Corallites near branch tips with less welldeveloped septa.

COLUMELLA: When present, a well-defined round to laterally flattened boss in the corallite center. Frequently missing, particularly in corallites near branch apices.

locations: Hanga Roa Hotel, 14-18 m, 18 March 1999, umml8.1597 (Figure 6A); Papa Haoa, 24-27 m; Motu Nui, $30 \mathrm{~m}$. ucmz 8.178 from Motu Iti, 3-10 m, March 1984, coll. C. Villalba: a small, flattened, complete colony missing one major branch, $172 \times 123 \times 67 \mathrm{~mm}$, prostate lateral branches with secondary branchlets, numerous well-developed verrucae, mostly appressed, not fusing, verrucae on all parts of branches including tips, average branch length $40 \mathrm{~mm}$, average branch diameter 15-20 mm, fairly evenly spaced corallites at branch tips but very evenly spaced at bases of branches, commensal vermetid worm at basis of a branch causes growth-form modification. UCMZ unnumbered: "Isla de Pascua," March 1984, coll. C. Villalba: a single main branch with 6 branchlets, $94 \times 34 \times 83 \mathrm{~mm}$, widely spaced branches, laterally flattened, verrucae strongly appressed and relatively small, densely crowded corallites at tips, uniformly spaced at bases, unequally spaced along sides of branches. UCMz 8.180 from Ovahe Bay, 9-10 m, March 1984, coll. C. Villalba: entire colony with multiple broken branches, $249 \times 180 \times 152 \mathrm{~mm}$, bushy colony, branches crowded, verrucae well developed, moderately appressed, all over branches including tips, corallites crowded near branch tips but frequently displaced by the numerous verrucae, more regular at bases of branches.

Notes: Due to difficulties associated with the taxonomic status of $P$. elegans Dana, 1846 and $P$. verrucosa, which cannot be satisfactorily separated due to cursory original descriptions and lost type specimens (see ReyesBonilla 2002), we decided to use the name P. verrucosa Pocillopora elegans would be a junior synonym if this problem could be resolved. Also, the descriptions in Veron (2000) suggest that our specimens are $P$. verrucosa. Veron (2000) distinguished the two species by irregular (P. verrucosa) versus regular ( $P$. elegans) verrucae.

Pocillopora ligulata Dana, 1846

Synonyms: (description in Maragos 1977).

Figure $6 C$

CORALLUM: Well-organized small clumps, usually rounded in appearance with neatly arranged branches. Diameters usually around $10 \mathrm{~cm}$. Branches radiate from a thick, submassive base that arches upward in its center and can attain several centimeters in thickness.
BRANCHES: Round near their bases, flattening out distally and becoming paddle-shaped toward tips. $\mathrm{Nu}$ merous secondary branches sprouting laterally, usually at $45^{\circ}$ angles from primary branches. Diameters around $1 \mathrm{~cm}$ at bases, up to $30 \mathrm{~mm}$ at spatulate tips, which display a contorted appearance.

VERRUCAE: Irregular and widely spaced, often appressed, usually thorny, decreasing in prominence toward base of branches. Diameters around $1 \mathrm{~mm}$. Verrucae appear analogous to branchlets in Acropora. Individual verrucae develop into branchlets (i.e., they become large and sprout secondary branchlets). This occurs in any region of the main branch and, if present at base of main branch, is a mechanism for initiation of secondary branches. Toward tips of branches verrucae are responsible for development of spatulate tips due to their fusion, which is achieved by initiation of a verruca between two already well-developed ones.

CALices: Haphazardly spaced over corallum, more widely spaced at branch bases (1 radius to 1 diameter apart) than at tips (usually $<1$ radius apart). No clear "cellular" arrangement at tips of branches as in most other species; however, calices are definitely more crowded at branch apices.

SEPTA: Rudimentary but clearly developed as laminae of about $1 / 8$ radius, always reaching bottom of calice, 10-12 septa.

COLUMella: Rudimentary, totally missing or in some calices moderately to well developed. Where present, an untidy structure of distally unfused, vertical, ornamented rods.

locations: Pirámide, 10-23 m; La Perouse Bay, 13 m, 14 March 1999, ummL8.1599 (Figure 6C); Papa Haoa (Henri's turtles), 24-27 m; Hanga Roa Hotel, 14-18 m; Hanga Roa Bay, 8-12 m; Motu Nui, 10-30 m; Anakena Cove, 7-9 m, ucmz 8.179, coll. C. Villalba, from Anakena, $10 \mathrm{~m}$, March 1984: complete specimen with one broken branch, size $228 \times 114 \times 117 \mathrm{~mm}$, branches relatively widely spread, entire colony consists of three main branches and their subbranchlets, well-developed paddle-shaped branch ends, branch diameters 15-30 $\mathrm{mm}$, major branch length $100 \mathrm{~mm}$, apical corallites crowded at tips ("sub-cellular"), evenly dispersed near bases; ucmz unnumbered, "Isla de Pascua," coll. C. Villalba: $175 \times 92 \times 77 \mathrm{~mm}$, entire colony, widely spaced branches, average branch length $60 \mathrm{~mm}$, corallites crowded at tips, equally distributed at bases, intermittently along sides. UCMz unnumbered, "Isla de Pascua," March 1984, coll. C. Villalba: solitary branch, $115 \times$ $27 \times 79 \mathrm{~mm}$, widely spaced branchlets, verrucae highly appressed, corallites crowded near tips, relatively evenly dispersed along sides of branches, uniformly along bases. ucMz unnumbered, "Isla de Pascua," coll. C. Villalba: $78 \times 59 \times 102 \mathrm{~mm}$, one main branch with 6 complete branchlets, 2 broken branchlets, corallites crowded at tips, intermittently along sides, evenly at bases, verrucae relatively small and strongly appressed. UCMZ unnumbered, "Isla de Pascua," coll. C. Villalba, March 1984: lacks tissue, one branch with 4 branchlets, $53 \times 39 \times 64$ $\mathrm{mm}$, widely flared, paddle-shaped branches, very crowded corallites near tips, more widely spaced along branch and at base, verrucae small and strongly appressed. 
NOTES: UCMZ 8.181, from Ovahe Bay, $8-10 \mathrm{~m}$, March 1984, coll. C. Villalba, a second tag reads Z-168: a complete, very large colony $(359 \times 196 \times 175 \mathrm{~mm})$ partial mortality at two edges, numerous commensal crabs, colony appears to be a chimera composed of about $2 / 3$ P. ligulata and $1 / 3$ P. damicornis. This is a new record for the Easter Island fauna.

\section{Pocillopora danae Verrill, 1864}

Figure $6 D$

CORALlum: Relatively small colonies, diameter around $20 \mathrm{~cm}$, compact, round to cushion-shaped, tidy clumps, originating from a usually encrusting base.

BRANCHES: Branch diameter $12-16 \mathrm{~mm}$, branches mostly vertical, all branches subdivided, prostate lateral branches bear secondary, upward-oriented branches. Distance between branches is about 1 branch diameter. Many branches become spatulate peripherally due to incomplete separation of branchlets.

VERRUCAE: Well-defined, regular, moderately appressed $\left(45^{\circ}\right.$ offset at most), increasing in size toward branch tips, at base of branches only present as low humps. Verrucae do not form branchlets and occur on all branch surfaces, even over branch tips.

CALICES: Regularly spaced over branch surfaces, somewhat greater intercalice distance toward branch bases (up to 1 diameter, on branches usually 1 radius). On verrucae sometimes arranged in rows but usually irregular. Coenosteal spines well developed as a ring of 16-20 spines attendant to theca and surrounding all calices regardless of their position on corallum.

SEPTA: Only developed as spines, never lamellar, but very clear when present (in almost all corallites).

columella: Usually absent.

locations: Hanga Roa Bay, 8-12 m; Hanga Roa Hotel, 14-18 m; La Perouse Bay, 13 m; Anakena Cove, 7-9 m, 16 March 1999, ummL8.1598 (Figure 6D); Motu Nui and Motu Iti, 8-40 m; Papa Haoa (Henri's turtles), 24-27 m; Colorado, 18-43 m; Pirámide, 10-23 m. ucMz 8.182 from Motu Iti, 3-10 m, March 1984, coll. C. Villalba: a complete, unbleached colony with commensal crab (Trapezia sp.), size $164 \times 143 \times 93 \mathrm{~mm}$, densely branching, compact cushion-shaped, branches 5-10 mm spacing, branch length up to $55 \mathrm{~mm}$, branches highly variable with several fully fused, prostate lateral branches, conforms well to description of characters.

Notes: The most complete specimen in the UMML collection is from Anakena Cove and corresponds well with the description in Vaughan (1918). We therefore believe this species to be sufficiently well defined to not consider it synonymous with $P$. verrucosa (DiSalvo et al. 1988, Glynn et al. 2003).

Pocillopora meandrina Dana, 1846

Figure $6 E$

CORALLUM: Large clumps with widely spaced branches. Branches can attain several centimeters in thickness and radiate from a thick, submassive base that arches upward in its center.

BRANCHES: Mostly laterally appressed with fairly regular, frequently dichotomous division into branchlets. Bases of branches clearly thicker than branchlets, which in sum of their diameters attain the thickness of their originating branch. Division of branches irregular but usually more frequent distally. Growth seems to continue from the base up, which appears to lead to "infilling" between branches. Branch diameters at base up to $5 \mathrm{~cm}$ (maximum) in laterally flattened branches, distal branches $1-2 \mathrm{~cm}$.

VERRUCAE: Fairly uniform in size, diameters $2-3$ $\mathrm{mm}$, frequently neatly arranged in rows. No fusions observed.

CALICES: More regularly spaced at bases of branches (intercalice distance 1 radius -1 diameter) than along their sides (intercalice distances up to 3-4 diameters). Often arranged in rows where rows are spaced at several corallite diameters from each other but calices within rows are immediately adjacent to each other. At branch tips crowded with clear "cellular" arrangement, where corallites are immediately adjacent to each other with no, or hardly any, coenosteal development in between.

SEPTA: Usually 12, 2 very distinct directive septa of size $1 / 4$ to $1 / 2$ radius.

columella: Rarely observed in specimens from Easter Island. According to Maragos more frequently (or regularly) observed in specimens from Hawai'i. Also we did not find any columella in specimens from Costa Rica and the Galápagos Islands.

Locations: Motu Nui, 10-30 m depth, 15 March 1999, uмmL8.1596 (Figure 6E, 2 specimens); Anakena Cove, 8 m; Hanga Piko, 8 m, October 1998, coll. H. Garcia; Pirámide, $10-20 \mathrm{~m}$.

Pocillopora damicornis (Linnaeus, 1758)

Figure $6 F$

CORALlum: Untidy clumps with spiky appearance due to numerous small branches formed by enlarged verrucae. Branches arise from an encrusting to submassive base.

BRANCHES: In the specimens reported here, thin for this species, diameters at bases around $1 \mathrm{~cm}$, peripherally 3-5 $\mathrm{mm}$. Branchlets clearly originate from enlarged verrucae and can subdivide repeatedly. Rounded in their basal parts, they become irregular in shape due to the sprouting of branchlets.

Verrucae: The longest and most "independent" of all Pocillopora species. Toward bases of branches verrucae tend to be attendant to main branches but sprout into branchlets once main branches have flared enough to offer space. Branchlets form throughout upper portions of branches. No fusion of verrucae or branchlets to form spatulate tips as in Pocillopora ligulata.

Calices: Diameter up to $1 \mathrm{~mm}$, toward branch tips sometimes larger, up to $1.5 \mathrm{~mm}$. Irregularly arranged over colony. Intercalice distance usually $<1$ calice diameter. Toward tips of branches they become more crowded, leading to development of polygonal calices. Calices occur all around and directly on branch and branchlet tips.

SEPTA: Absent in most corallites. Sometimes rudiments of up to two cycles of $1 / 10$ calice radius. 
columella: Absent in most corallites; if present, only a small boss.

Locations: Hanga Roa Bay, 13 m, 14 March 1999, umML8.1594 (Figure 6F); Papa Haoa, 25 m.

Pocillopora eydouxi Milne Edwards \& Haime, 1860

Figure $6 G$

corallum: The largest species of Pocillopora on Easter Island. Handsome colonies with thick, fairly regularly spaced branches that subdivide repeatedly. Long and often quite well-separated branches arising from a thick base, which can attain several centimeters in area. Diameter up to $40 \mathrm{~cm}$. An easily recognized species.

BRANCHES: Usually oval, even at the branch bases. Secondary branches arise from all regions of main branches. If branching near apex, branch tips maintain their identity and do not fuse to form meandering networks (as in P. meandrina). The sum of old and new branches forms a laterally strongly compressed neat cluster of linearly arranged tips.

VERRUCAE: Regularly arranged along branches, of uniform size, diameters $2-3 \mathrm{~mm}$, mostly almost at righ angles to branch. Verrucae decrease in size toward branch tips, where they are barely noticeable but still present. Calices uniformly distributed over verrucae, including tips. Verrucae never sprout branchlets.

CALICES: Occurring all over branches and verrucae. Diameter around $0.7-1 \mathrm{~mm}$, irregular but typically in a dense arrangement. Intercalice distance usually $<1$ radius. At branch tips crowded with a clear "cellular" arrangement, there is hardly any coenosteal development. Density and ornamentation of coenosteal spines between calices increase toward branch bases.

SEPTA: Usually well developed in two cycles $(1 / 4 \mathrm{ra}-$ dius), more or less prominent and development can vary within and among colonies.

locations: Hanga Piko, 8 m, October 1998, coll. H. Garcia; Motu Nui, 30 m, 15 March 1999, ummL8.1595 (Figure 6G); Pirámide, $18 \mathrm{~m}$; Anakena Cove, $10 \mathrm{~m}$.

Notes: Wells (1972) mistakenly identified worn fragments of P. eydouxi as Pocillopora diomedeae but corrected this in DiSalvo et al. (1988). None of our specimens of Pocillopora match Vaughan's (1906) description of $P$. diomedeae.

\section{Suborder Poritinn \\ Family Poritidae}

Porites lobata Dana, 1846

Figure $7 A-G$

CORALLUM: A wide variety of growth-forms but basically massive to (sub)columnar. Almost all colonies with more or less well-developed columns or lobed protuberances. Other common growth forms include blades, hillocks, and thick spikes.

corallites: Mostly round to polygonal where crowded.

SEPTA: Despite remarkable corallum variability, septal patterns are very stable throughout the series of speci- mens. A fairly large dorsal directive septum is present that ranges in size from $1 / 2$ length of lateral pairs to same length. Ventral triplet is characteristically free. Rarely are lateral septa in triplet fused to ventral directive septum. Never full, trident-shaped fusion. Ventral directive septum frequently shorter than two attendant lateral septa in triplet. Four complete lateral pairs of septa fused at their tips. A distinct, strongly ornamented palus found at point of fusion of lateral septal pairs and usually also on directive septa. Frequently, however, not all septa of ventral triplet in possession of a palus. Also, one ornamented spicule exists in middle of septum. Lateral dentition usually present but of variable prominence. Well-developed palar ring.

columella: Always present and well developed, oval, compressed in direction of directive septa (i.e., broad side facing lateral septa). Usually strong trabecular linkage to palar ring.

THECAE: Well developed and acute, with between 1 and 3 rows of ornamented large spines. On wide thecae (when corallites are not crowded) the 2 lateral rows of spines are low, leaving central row prominent and vertically oriented. Spines have a tendency to fuse in their distal parts and thus form an acute ridge.

locations: Papa Haoa, $28 \mathrm{~m}$ (6 specimens), 15 March 1999, ummL8.1592 (Figure 7C), ummL8.1591 (Figure 7D); Hanga Roa Bay, 10-14 m (3 specimens), 14 March 1999, umml8.1593 (Figure 7B); Hanga Tee pool, tide pools with macroalgae, $0.5 \mathrm{~m}$ (4 specimens); Pirámide, 16-25 m (13 specimens), 18 March 1999, umml8.1589 (Figure 7E); La Perouse Bay, 10-14 m, 14 March 1999, ummL8.1588 (Figure 7A); Anakena Cove, 8-10 m, 16 March 1999, UMmL8.1590 (Figure $7 F$ ). ucmz 8.177, Hanga Piko, March 1984, coll. C. Villalba: a small lobe, $58 \times 50 \times 79 \mathrm{~mm}$, probably from a tide pool because the colony was flat and partly dead at top, corallite characteristics conform to description; UCMZ 8.176, Hanga Piko, March 1984, coll. C. Villalba: a colony recovering from previous mortality and resheeting old skeleton, $139 \times 85 \times 170 \mathrm{~mm}$, two well-developed lobes, one lesser lobe; ucmz 8.175, from Hanga Piko, March 1984, coll. C. Villalba, a second tag reads Z-166, complete colony from shallow environment, very squat morphology with flattened tops, $129 \times 110 \times 126 \mathrm{~mm}$. UCMZ unnumbered, March 1984, coll. C. Villalba: an encrusting colony overgrowing a volcanic pebble, $138 \times$ $74 \times 58 \mathrm{~mm}$.

NOTEs: Our determination that all specimens belong to $P$. lobata only is primarily based on the characteristics of the ventral triplet and columella, which have been shown to be the most stable characters and thus the most useful for species discrimination in the otherwise highly variable Porites calices (Riegl and Piller 1997). The ubiquitous absence of fusion in our specimens clearly differentiates them from Porites lutea and Porites australiensis, which otherwise are morphologically very similar. The morphological characters of the Porites corallites in our collection are remarkably stable. The presence of pali differentiates this species from Porites solida (Veron \& Pichon 1982). Wells (1972, 1983) concluded that Porites paschalensis (Vaughan, 1906) was a junior synonym of Porites lobata. 


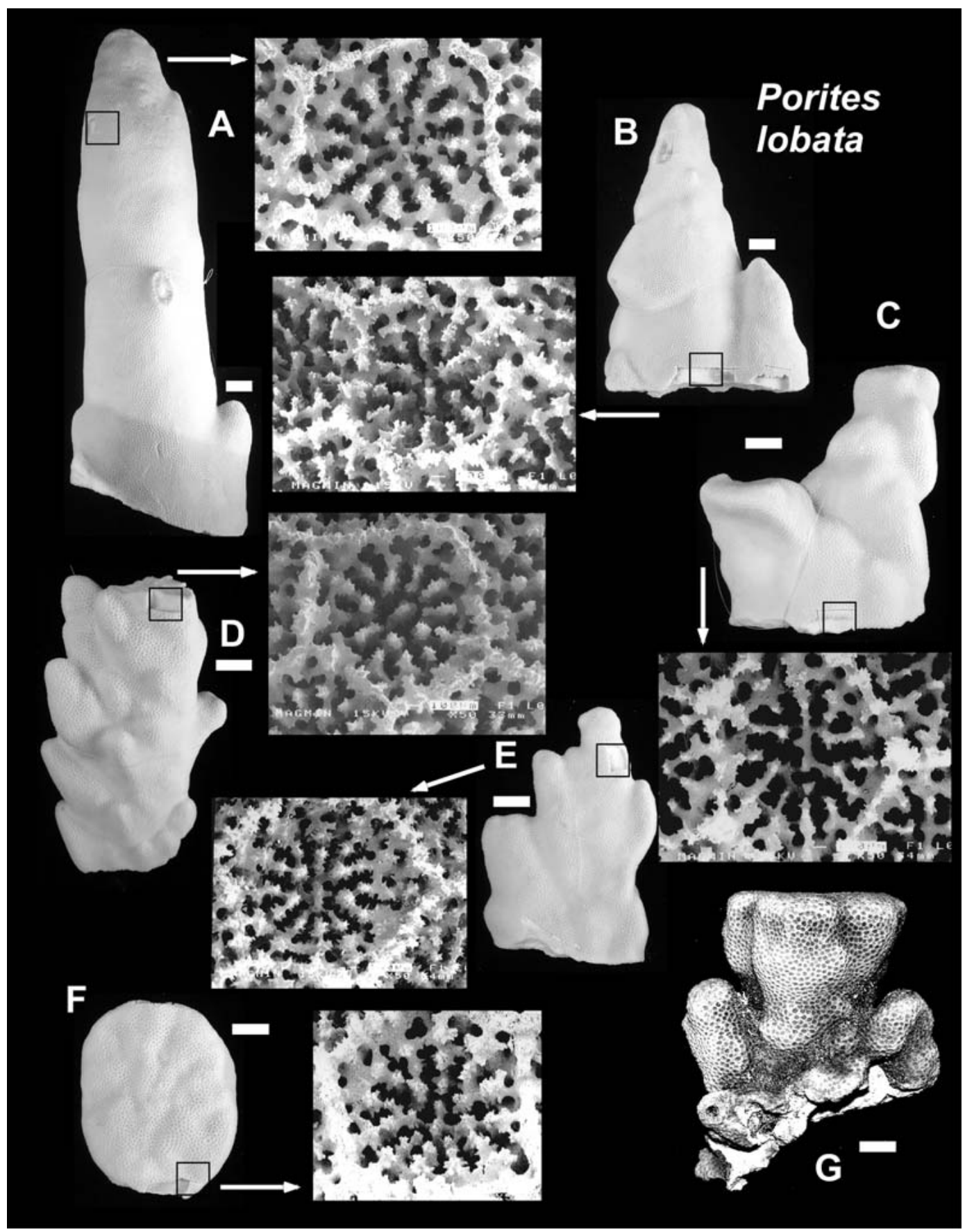

FIGURE 7. Gross morphology and calice details of $P$. lobata from Easter Island in the UmmL collection. The provenance of the calices shown in the insets is marked by a black square. Scale bar $=10 \mathrm{~mm}$ with reference to the corallum. All specimens are from subtidal habitats except $G$, which is a flat-topped specimen from a tidal pool (without calice details). Colony in $G$ is UCMz 8.177. Note wide variation in growth forms in juxtaposition to remarkable stability in calice characteristics. 
Suborder FungIINA

Family AgariciddaE

Leptoseris scabra Vaughan, 1907

Synonym: Leptoseris tubulifera Vaughan, 1907 Figure $8 A$

CORALLUM: Basically a unifacial frond, edges become contorted and roll up to form cylindrical tubes. As edges continue to grow outward, these tubes move to more central positions on colony so that at least in one specimen most of colony's surface was covered by branched or unbranched vertical tubes.

CoRAllites: Irregular in size (diameter 5 to $12 \mathrm{~mm}$ ), slightly immersed and not outwardly inclined, irregularly spaced, sometimes forming short series of up to two mouths.

costae: Generally equal, in some places a smaller cycle present, continuous between calices and over tubes, not all costae reach calices and become septa.

SEPTA: In direct continuation of costae, mostly of equal size, sometimes a smaller cycle visible.

columella: Flat, spatulate, with ornamentation, not present in all corallites.

locations: Hanga Roa Hotel, 43 m, 18 March 1999, coll. H. Garcia, ummL8.1604 (Figure 8A).

NOTES: The specimen corresponds well with the descriptions in Maragos (1977) and Veron (2000). Veron and Pichon (1979) considered this species a junior synonym of L. scabra Vaughan.

Leptoseris solida (Quelch, 1886)

Synonym: Leptoseris paschalensis Wells, 1972

Figure $8 B$

corallum: Encrusting to unifacial laminae. According to Veron (2000) corallites lack a conspicuous central corallite. One of our specimens is a complete, platelike colony with several clearly visible central corallites slightly larger than those surrounding them. The other specimens lack a center. On corallites and sometimes in between, proliferations of coenosteum create corallite-like mounds that give the colonies an irregular and "spiky" appearance.

CORALLITES: In irregular but largely concentric rings, steeply inclined toward colony edge, reaching an angle of $90^{\circ}$ to surface of colony, average diameter around $1-1.5 \mathrm{~mm}$.

CostaE: In two clear alternating size classes, finely granulated, not all costae reach calices to become septa. On underside of corallum, all costae belong to one size class. On upper walls of corallites, costae frequently flare and contort to form the mounds typical of this species.

SEPTA: In two size classes but not alternating cycles.

columella: Well developed but seated deeply inside calices and not always readily visible.

Locations: Hanga Roa Bay, southern point, 80$100 \mathrm{~m}$, November 2004, ummL8.1605 (Figure 8B, fragment on right), from a drag haul over sand and hard bottom, coll. M. Garcia. Motu Nui, 70 m, 19 March 1999, uмmL8.1606 (Figure 8B, fragment on left), coll. H. Garcia.
Notes: The specimens from Easter Island are very similar to the description and illustrations of L. paschalensis in Wells (1972). We follow Wells (1983) and Glynn et al. (2003) in considering $L$. paschalensis a synonym of L. solida (Quelch).

\section{Suborder AstrocoeniIna}

Family ThamNasteriIDAE

\section{Psammocora stellata (Verrill, 1866)}

\section{Figure $8 C, D$}

CORALlum: Short, irregular branches arising from an encrusting to submassive base. Coralla are small, mostly $<10 \mathrm{~cm}$ diameter, with branches up to $5 \mathrm{~cm}$ in length, diameter around $1-1.5 \mathrm{~cm}$. Surfaces of all coralla have small collines, which can develop into branches. This gives surfaces of coralla a distinctly "uneven" appearance.

corallites: Polygonal and shallow with poorly to well-defined walls. Diameters 1-3 mm. Especially on branches, corallite walls not of same height on all sides, which leads to an arrangement of short series of corallites united by taller lateral walls separating them from the neighboring series of corallites but low and fairly indistinct walls in between corallites of same series. Wall less acute on branches than on flat parts of corallum. A clear gradation between the two morphologies, however, is visible within the same specimen.

SEPTA: Septa 12-20 (usually always more than 12) developed as septo-costae. Mostly of one size class, laterally strongly ornamented (the multitrabecular spines on edge of septa continue over their sides), several septa can fuse near calice center. Numerous tear-shaped septa, which, according to Veron (2000), is characteristic of this species. However, these are not always visible. In many calices a clear alternation of tear-shaped (discontinuous) and nonflaring but continuous septocostae are visible. In some calices, every second septum is tear-shaped and discontinuous, but this situation varies both among colonies and specimens. In some parts of the corallum, the tearshaped septa are clearly thicker and raised above surface of other septo-costae.

columella: Present in almost all corallites, consisting of vertical rods that are fused further down in calice. Tips of vertical rods free when viewed from above.

Locations: Colorado, 40 m, 17 March 1999, coll. H. Garcia; Hanga Roa Bay, 7-10 m; La Perouse Bay, 8 m; Pirámide, 15 m; Hanga Roa Hotel, 8 m, 20 March 2000 , locality and depth unknown, ummL 8.1601 (Figure $8 C$ ); collecting information unknown, umML8.1600 (Figure $8 D$ ).

NOTES: The specimens reported here correspond well with illustrations in Wells (1983) and Veron (2000). One specimen showed more variability, with fewer tearshaped septa; only one clearly developed, strongly dentate cycle; and variable thecae (locality unknown, March 2000 , coll. E. A. Wieters). Psammocora obtusangula was recorded by Cortés and Guzmán (1998) from Costa Rica, and the calicular characteristics of some of our specimens from Easter Island correspond to their specimens. However, the fragments are very small and it is possible that they are misinterpreted morphs of $P$. stellata according 


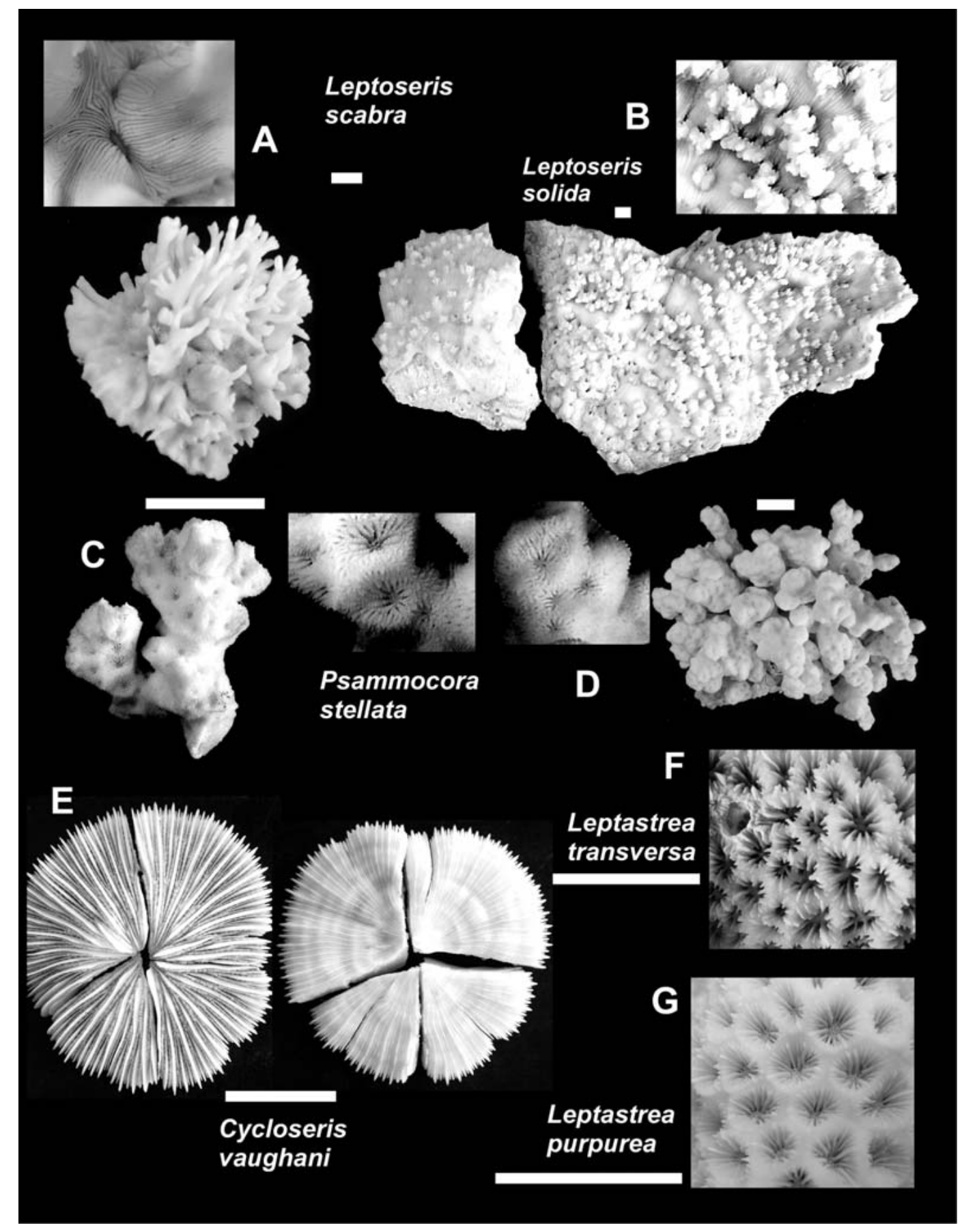

Figure 8. Coral species from Easter Island in the ummL collection. Scale bar $=10 \mathrm{~mm}$ and only applicable to whole corallum. A, Leptoseris scabra, colony with vertically oriented cylindrical tubes; $B, L$. solida, platelike colonies with corallites and corallite-like mounds arranged in irregular concentric rings; $C, D$, Psammocora stellata, colony with irregular stubby branches and small depressed corallites; E, Cycloseris vaughani, disklike colony with two to three cycles of serrate costae; F, Leptastrea transversa, septa nearly smooth and exsert, descending steeply into calice bearing an inconspicuous columella; $G, L$. purpurea, septa finely serrated and weakly exsert, descending gradually into calice with a welldeveloped columella. 
to F. Benzoni (pers. comm.), who also pointed out the poorly defined status of $P$. obtusangula, which was noted by Hoffmeister (1925). We were unable to confirm the presence of Psammocora superficialis as reported by Glynn et al. (2003).

\section{Family FungIIDAE}

Cycloseris vaughani (Boschma, 1923) Figure $8 E$

CORAllum: One specimen $2.5-2.8 \mathrm{~cm}$ diameter, height $4.9 \mathrm{~mm}$; second specimen $3.7-3.8 \mathrm{~cm}$ diameter, height $7.0 \mathrm{~mm}$; generally flat, slightly concave on underside; outline more or less circular with moderate peripheral scalloping; very moderate arching of septa toward center. Corallum breaks into regular pie-shaped segments.

costae: Cycles two to three, one primary, two secondary cycles; parallel, fine, serrate with regular, acutely angular dentitions; all costae reach center, well exsert near margins, almost disappear toward center, clear attachment scar, several well-developed suture lines.

SEPTA: Cycles four, three well developed, fourth small and granular; one primary cycle, elevated moderately toward center descending abruptly toward columella, edges denticulate, regular, symmetrical denticles, which are single teeth without ornamentation, sides papillate, well exsert at corallum's edge; second cycle also moderately elevated toward center, septa descend abruptly more peripherally than in first cycle and not all reach columella; third cycle only well developed on periphery, septa descend and disappear at around 1/3-1/2 radius from margin, exsert on corallum margin; third cycle strongly ornamented, synapticulae present; fourth cycle generally lower than other cycles, strongly dentate, multiple fusions, toward center all fourth-cycle septa tend to fuse with third cycle; some septa on one specimen angled in typical Diaseris-type fashion.

columella: Present in both specimens; weakly developed, spongy, consisting of tangled teeth originating from septa's (all cycles) inner edges.

LOcation: Along shore between Anakena Cove and Ovahe Bay, 100 m, November 2004, ummL8.1607 (Figure $8 E)$, coll. M. Garcia.

NOTEs: Reportedly also common at Motu Nui.

\section{Suborder FaviINA}

Family FAVIIDAE

\section{Leptastrea transversa Klunzinger, 1879} Figure $8 F$

Corallum: Massive, with irregular outline and irregular surface.

CAlices: Plocoid (subcerioid sensu Veron et al. [1977]), polygonal, and irregular in size. Often crowded and protuberant.
SEPTA: In primarily two, often also three, clearly distinguishable size classes. Larger size class consists of either 6 or 12 septa and is at least twice as thick and long (in terms of proportion of radius) as smaller size class. Usually only first size class reaches columella and is fused to it. Septa descend steeply into calice and have only very fine serrations and lateral granulations so as to appear almost smooth. Larger cycle is well exsert and thickened. No clear paliform lobes (or teeth) were observed in our specimens.

columella: Present but less conspicuous than in L. purpurea. Consists of fully fused vertical rods without free ends so that columella is a single, undifferentiated structure.

Locations: Anakena Cove, 8-10 m, 16 March 1999, umml8.1602 (Figure 8F); Pirámide, 16-19 m, March 2000; Ovahe Bay, 12 m, March 2005, coll. E. Borneman; Motu Tautara, $20 \mathrm{~m}$, March 2000, rounded boulders in an erosional depression, coll. D. K. Hubbard.

NOTES: This is the first record of Leptastrea transversa collected at Easter Island. A single fragment from one colony of this species was collected in 1999 but not listed in Glynn et al. (2003).

Leptastrea purpurea (Dana, 1846)

Figure $8 G$

corallum: Massive, small colonies encrusting to submassive, often irregular colony outline. At least two colonies show clear evidence of "resheeting" (i.e., renewed overgrowth by live tissue of previously dead parts of colony).

CAlices: Plocoid (subcerioid sensu Veron et al. [1977]), mostly polygonal, a clear groove separates calices, diameters $1-4 \mathrm{~mm}$.

SEPTA: Around 30, in up to three size classes, small septa sometimes fuse to larger septa, thus only larger septa class (usually the largest cycles) reach center of calice, where they fuse to columella. Size difference between septal cycles less pronounced than in L. transversa. Septa descend gently into calice, are finely serrated on their upper edges and granulated on sides. Septa weakly exsert. No clear paliform lobes (or teeth) were observed in our specimens.

columella: Well developed and conspicuous, consisting of fused vertical rods with free tips.

Locations: Hanga Roa Bay, dive 1, 10 m, 14 March 1999, 5 specimens, coll. P. W. Glynn; Pirámide, $21 \mathrm{~m}$, 16 March 2005, ummL8.1603 (Figure 8G), coll. E. A. Wieters.

Notes: Within our series of $L$. purpurea and $L$. transversa, at least two specimens show characters of both species and are thus in morphological transition. An example is a typical $L$. transversa-type septal arrangement with two clear size classes but quite strongly serrated and granulated septa of $L$. purpurea type that meet an $L$. transversa-type columella. These specimens were collected among rounded boulders at Motu Tautara (20 m depth) by D. K. Hubbard in March 2003. 
Diversity and Biogeography of Easter Island Corals · Glynn et al.

Appendix 2

Presence/Absence of Zooxanthellate Scleractinian Coral Species at 19 Localities in the Eastern, Southeastern, and Central Pacific Ocean

\begin{tabular}{|c|c|c|c|c|c|c|c|c|c|c|c|c|c|c|c|c|c|c|c|}
\hline & soc & TUA & GAM & AUs & MAR & HAW & PIT & MEM & REV & CLP & CRC & $\mathrm{coc}$ & PAN & $\mathrm{COL}$ & MAL & ECD & GAL & FAN & EAS \\
\hline $\begin{array}{c}\text { Stylocoeniella } \\
\text { guentberi }\end{array}$ & 1 & 1 & 0 & 1 & 0 & 0 & 1 & 0 & 0 & 0 & 0 & 0 & 0 & 0 & 0 & 0 & 0 & 0 & 0 \\
\hline S. nikei & 0 & 0 & 0 & 1 & 0 & 0 & 0 & 0 & 0 & 0 & 0 & 0 & 0 & 0 & 0 & 0 & 0 & 0 & 0 \\
\hline S. paumotensis & 0 & 1 & 0 & 0 & 0 & 0 & 0 & 0 & 0 & 0 & 0 & 0 & 0 & 0 & 0 & 0 & 0 & 0 & 0 \\
\hline Stylophora pistillata & 0 & 1 & 1 & 0 & 0 & 0 & 0 & 0 & 0 & 0 & 0 & 0 & 0 & 0 & 0 & 0 & 0 & 0 & 0 \\
\hline Pocillopora capitata & 0 & 0 & 0 & 0 & 0 & 0 & 0 & 1 & 1 & 0 & 1 & 1 & 1 & 1 & 1 & 1 & 1 & 0 & 0 \\
\hline P. damicornis & 1 & 1 & 1 & 1 & 1 & 1 & 1 & 1 & 1 & 0 & 1 & 1 & 1 & 1 & 0 & 1 & 1 & 0 & 1 \\
\hline P. eydouxi & 1 & 1 & 1 & 0 & 0 & 1 & 1 & 1 & 1 & 0 & 1 & 1 & 1 & 1 & 1 & 1 & 1 & 1 & 1 \\
\hline P. inflata & 0 & 0 & 0 & 0 & 0 & 0 & 0 & 1 & 0 & 0 & 1 & 0 & 1 & 0 & 0 & 0 & 1 & 0 & 0 \\
\hline P. meandrina & 0 & 0 & 0 & 0 & 0 & 1 & 0 & 1 & 1 & 1 & 1 & 1 & 1 & 0 & 0 & 0 & 1 & 1 & 1 \\
\hline P. effusus & 0 & 0 & 0 & 0 & 0 & 0 & 0 & 1 & 0 & 1 & 0 & 0 & 0 & 0 & 0 & 0 & 1 & 0 & 0 \\
\hline$P$. verrucosa & 1 & 1 & 1 & 1 & 1 & 0 & 0 & 1 & 1 & 1 & 1 & 1 & 1 & 1 & 1 & 1 & 1 & 0 & 1 \\
\hline P. woodjonesi & 1 & 0 & 0 & 0 & 0 & 0 & 1 & 0 & 1 & 0 & 0 & 0 & 0 & 0 & 0 & 0 & 0 & 0 & 0 \\
\hline P. danae & 1 & 1 & 0 & 0 & 1 & 0 & 0 & 0 & 0 & 0 & 0 & 0 & 0 & 0 & 0 & 0 & 0 & 0 & 1 \\
\hline P. sp. 1 & 0 & 0 & 0 & 0 & 0 & 0 & 1 & 0 & 0 & 0 & 0 & 0 & 0 & 0 & 0 & 0 & 0 & 0 & 0 \\
\hline P. molokensis & 0 & 0 & 0 & 0 & 0 & 1 & 0 & 0 & 0 & 0 & 0 & 0 & 0 & 0 & 0 & 0 & 0 & 0 & 0 \\
\hline P. solida & 1 & 1 & 0 & 0 & 0 & 0 & 0 & 0 & 0 & 0 & 0 & 0 & 0 & 0 & 0 & 0 & 0 & 0 & 0 \\
\hline P. ligulata & 0 & 0 & 0 & 0 & 0 & 1 & 0 & 0 & 0 & 0 & 0 & 0 & 0 & 0 & 0 & 0 & 0 & 0 & 1 \\
\hline Montipora capitata & 0 & 0 & 0 & 0 & 0 & 1 & 1 & 0 & 0 & 0 & 0 & 0 & 0 & 0 & 0 & 0 & 0 & 0 & 0 \\
\hline M. dilatata & 0 & 0 & 0 & 0 & 0 & 1 & 0 & 0 & 0 & 0 & 0 & 0 & 0 & 0 & 0 & 0 & 0 & 0 & 0 \\
\hline M. flabellata & 0 & 0 & 0 & 0 & 0 & 1 & 0 & 0 & 0 & 0 & 0 & 0 & 0 & 0 & 0 & 0 & 0 & 0 & 0 \\
\hline M. patula & 0 & 0 & 0 & 0 & 1 & 1 & 0 & 0 & 0 & 0 & 0 & 0 & 0 & 0 & 0 & 0 & 0 & 0 & 0 \\
\hline M. tuberculosa & 1 & 1 & 0 & 0 & 1 & 1 & 1 & 0 & 0 & 0 & 0 & 0 & 0 & 0 & 0 & 0 & 0 & 0 & 0 \\
\hline M. verrilli & 1 & 1 & 1 & 1 & 1 & 1 & 0 & 0 & 0 & 0 & 0 & 0 & 0 & 0 & 0 & 0 & 0 & 0 & 0 \\
\hline M. australiensis & 1 & 0 & 0 & 0 & 0 & 0 & 0 & 0 & 0 & 0 & 0 & 0 & 0 & 0 & 0 & 0 & 0 & 0 & 0 \\
\hline M. aspera & 1 & 0 & 0 & 0 & 0 & 0 & 0 & 0 & 0 & 0 & 0 & 0 & 0 & 0 & 0 & 0 & 0 & 0 & 0 \\
\hline M. foliosa & 1 & 0 & 0 & 1 & 0 & 0 & 0 & 0 & 0 & 0 & 0 & 0 & 0 & 0 & 0 & 0 & 0 & 0 & 0 \\
\hline M. millepora & 0 & 0 & 0 & 1 & 0 & 0 & 0 & 0 & 0 & 0 & 0 & 0 & 0 & 0 & 0 & 0 & 0 & 0 & 0 \\
\hline M. turgescens & 0 & 1 & 0 & 0 & 0 & 1 & 0 & 0 & 0 & 0 & 0 & 0 & 0 & 0 & 0 & 0 & 0 & 0 & 0 \\
\hline M. spumosa & 1 & 0 & 0 & 0 & 0 & 0 & 0 & 0 & 0 & 0 & 0 & 0 & 0 & 0 & 0 & 0 & 0 & 0 & 0 \\
\hline M. lichen & 1 & 0 & 0 & 0 & 0 & 0 & 0 & 0 & 0 & 0 & 0 & 0 & 0 & 0 & 0 & 0 & 0 & 0 & 0 \\
\hline M. floweri & 1 & 1 & 0 & 0 & 0 & 0 & 0 & 0 & 0 & 0 & 0 & 0 & 0 & 0 & 0 & 0 & 0 & 0 & 0 \\
\hline M. erythrea & 1 & 0 & 0 & 0 & 0 & 0 & 0 & 0 & 0 & 0 & 0 & 0 & 0 & 0 & 0 & 0 & 0 & 0 & 0 \\
\hline M. elschneri & 0 & 1 & 1 & 1 & 0 & 0 & 0 & 0 & 0 & 0 & 0 & 0 & 0 & 0 & 0 & 0 & 0 & 0 & 0 \\
\hline M. effusa & 1 & 0 & 0 & 0 & 0 & 0 & 0 & 0 & 0 & 0 & 0 & 0 & 0 & 0 & 0 & 0 & 0 & 0 & 0 \\
\hline M. hoffmeisteri & 0 & 0 & 0 & 1 & 0 & 0 & 0 & 0 & 0 & 0 & 0 & 0 & 0 & 0 & 0 & 0 & 0 & 0 & 0 \\
\hline M. edwardsi & 0 & 1 & 0 & 0 & 0 & 0 & 0 & 0 & 0 & 0 & 0 & 0 & 0 & 0 & 0 & 0 & 0 & 0 & 0 \\
\hline M. aequituberculata & 1 & 1 & 0 & 1 & 0 & 0 & 1 & 0 & 0 & 0 & 0 & 0 & 0 & 0 & 0 & 0 & 0 & 0 & 0 \\
\hline M. composita & 0 & 0 & 0 & 1 & 0 & 0 & 0 & 0 & 0 & 0 & 0 & 0 & 0 & 0 & 0 & 0 & 0 & 0 & 0 \\
\hline M. bilaminata & 0 & 0 & 0 & 1 & 0 & 0 & 1 & 0 & 0 & 0 & 0 & 0 & 0 & 0 & 0 & 0 & 0 & 0 & 0 \\
\hline M. caliculata & 0 & 1 & 1 & 1 & 0 & 0 & 1 & 0 & 0 & 0 & 0 & 0 & 0 & 0 & 0 & 0 & 0 & 0 & 0 \\
\hline M. danae & 0 & 0 & 0 & 1 & 0 & 0 & 0 & 0 & 0 & 0 & 0 & 0 & 0 & 0 & 0 & 0 & 0 & 0 & 0 \\
\hline M. foveolata & 1 & 1 & 1 & 1 & 0 & 0 & 1 & 0 & 0 & 0 & 0 & 0 & 0 & 0 & 0 & 0 & 0 & 0 & 0 \\
\hline M. explanulata & 0 & 0 & 0 & 1 & 0 & 0 & 0 & 0 & 0 & 0 & 0 & 0 & 0 & 0 & 0 & 0 & 0 & 0 & 0 \\
\hline M. bispida & 0 & 1 & 0 & 1 & 0 & 0 & 0 & 0 & 0 & 0 & 0 & 0 & 0 & 0 & 0 & 0 & 0 & 0 & 0 \\
\hline M. grisea & 0 & 0 & 0 & 0 & 0 & 0 & 1 & 0 & 0 & 0 & 0 & 0 & 0 & 0 & 0 & 0 & 0 & 0 & 0 \\
\hline M. informis & 0 & 1 & 1 & 1 & 0 & 0 & 0 & 0 & 0 & 0 & 0 & 0 & 0 & 0 & 0 & 0 & 0 & 0 & 0 \\
\hline M. incrassata & 0 & 0 & 0 & 0 & 0 & 0 & 1 & 0 & 0 & 0 & 0 & 0 & 0 & 0 & 0 & 0 & 0 & 0 & 0 \\
\hline M. complanata & 0 & 0 & 0 & 0 & 0 & 0 & 1 & 0 & 0 & 0 & 0 & 0 & 0 & 0 & 0 & 0 & 0 & 0 & 0 \\
\hline M. venosa & 1 & 1 & 1 & 1 & 0 & 0 & 1 & 0 & 0 & 0 & 0 & 0 & 0 & 0 & 0 & 0 & 0 & 0 & 0 \\
\hline M. studeri $=$ verrucos $a$ & 1 & 1 & 1 & 1 & 0 & 1 & 1 & 0 & 0 & 0 & 0 & 0 & 0 & 0 & 0 & 0 & 0 & 0 & 0 \\
\hline Acropora valida & 1 & 1 & 1 & 1 & 0 & 1 & 1 & 0 & 0 & 0 & 0 & 0 & 0 & 0 & 0 & 0 & 0 & 0 & 0 \\
\hline A. abrotanoides & 1 & 1 & 1 & 1 & 0 & 0 & 0 & 0 & 0 & 0 & 0 & 0 & 0 & 0 & 0 & 0 & 0 & 0 & 0 \\
\hline A. cytherea & 1 & 1 & 0 & 1 & 0 & 1 & 1 & 0 & 0 & 0 & 0 & 0 & 0 & 0 & 0 & 0 & 0 & 0 & 0 \\
\hline A. bumilis & 1 & 1 & 1 & 1 & 0 & 1 & 1 & 0 & 0 & 0 & 0 & 0 & 0 & 0 & 0 & 0 & 0 & 0 & 0 \\
\hline
\end{tabular}


Appendix 2 (continued)

\begin{tabular}{|c|c|c|c|c|c|c|c|c|c|c|c|c|c|c|c|c|c|c|c|}
\hline & soc & TUA & GAM & AUS & MAR & HAW & PIT & MEM & REV & CLP & CRC & coc & PAN & $\mathrm{COL}$ & MAL & ECD & GAL & FAN & EAS \\
\hline A. paniculata & 1 & 0 & 0 & 0 & 0 & 1 & 0 & 0 & 0 & 0 & 0 & 0 & 0 & 0 & 0 & 0 & 0 & 0 & 0 \\
\hline A. acuminata & 0 & 0 & 0 & 0 & 0 & 0 & 1 & 0 & 0 & 0 & 0 & 0 & 0 & 0 & 0 & 0 & 0 & 0 & 0 \\
\hline A. loripes & 1 & 0 & 1 & 1 & 0 & 0 & 0 & 0 & 0 & 0 & 0 & 0 & 0 & 0 & 0 & 0 & 0 & 0 & 0 \\
\hline A. gemmifera & 1 & 0 & 1 & 0 & 0 & 0 & 0 & 0 & 0 & 0 & 0 & 0 & 0 & 0 & 0 & 0 & 0 & 0 & 0 \\
\hline A. digitifera & 1 & 0 & 1 & 1 & 0 & 0 & 1 & 0 & 0 & 0 & 0 & 0 & 0 & 0 & 0 & 0 & 0 & 0 & 0 \\
\hline A. glauca & 0 & 0 & 0 & 0 & 0 & 0 & 1 & 0 & 0 & 0 & 0 & 0 & 0 & 0 & 0 & 0 & 0 & 0 & 0 \\
\hline A. latistella & 1 & 1 & 0 & 0 & 0 & 0 & 1 & 0 & 0 & 0 & 0 & 0 & 0 & 0 & 0 & 0 & 0 & 0 & 0 \\
\hline A. lutkeni & 1 & 1 & 0 & 0 & 0 & 0 & 1 & 0 & 0 & 0 & 0 & 0 & 0 & 0 & 0 & 0 & 0 & 0 & 0 \\
\hline A. microclados & 0 & 0 & 0 & 0 & 0 & 0 & 1 & 0 & 0 & 0 & 0 & 0 & 0 & 0 & 0 & 0 & 0 & 0 & 0 \\
\hline A. nasuta & 1 & 1 & 1 & 0 & 0 & 1 & 1 & 0 & 0 & 0 & 0 & 0 & 0 & 0 & 0 & 0 & 0 & 0 & 0 \\
\hline A. secale & 1 & 1 & 0 & 1 & 0 & 0 & 1 & 0 & 0 & 0 & 0 & 0 & 0 & 0 & 0 & 0 & 0 & 0 & 0 \\
\hline A. samoensis & 1 & 0 & 0 & 0 & 0 & 0 & 0 & 0 & 0 & 0 & 0 & 0 & 0 & 0 & 0 & 0 & 0 & 0 & 0 \\
\hline A. speciosa & 1 & 1 & 0 & 0 & 0 & 0 & 0 & 0 & 0 & 0 & 0 & 0 & 0 & 0 & 0 & 0 & 0 & 0 & 0 \\
\hline A. sarmentosa & 1 & 1 & 0 & 0 & 0 & 0 & 0 & 0 & 0 & 0 & 0 & 0 & 0 & 0 & 0 & 0 & 0 & 0 & 0 \\
\hline A. solitaryensis & 0 & 0 & 0 & 0 & 0 & 0 & 1 & 0 & 0 & 0 & 0 & 0 & 0 & 0 & 0 & 0 & 0 & 0 & 0 \\
\hline A. rosaria & 0 & 0 & 0 & 1 & 0 & 0 & 0 & 0 & 0 & 0 & 0 & 0 & 0 & 0 & 0 & 0 & 0 & 0 & 0 \\
\hline A. robusta & 1 & 1 & 0 & 1 & 0 & 0 & 0 & 0 & 0 & 0 & 0 & 0 & 0 & 0 & 0 & 0 & 0 & 0 & 0 \\
\hline A. byacintbus & 1 & 1 & 1 & 1 & 0 & 0 & 0 & 0 & 0 & 0 & 0 & 0 & 0 & 0 & 0 & 0 & 0 & 0 & 0 \\
\hline A. baimei & 0 & 0 & 0 & 1 & 0 & 0 & 0 & 0 & 0 & 0 & 0 & 0 & 0 & 0 & 0 & 0 & 0 & 0 & 0 \\
\hline A. granulosa & 1 & 1 & 0 & 1 & 0 & 0 & 0 & 0 & 0 & 0 & 0 & 0 & 0 & 0 & 0 & 0 & 0 & 0 & 0 \\
\hline A. formosa & 0 & 0 & 0 & 1 & 0 & 0 & 0 & 0 & 0 & 0 & 0 & 0 & 0 & 0 & 0 & 0 & 0 & 0 & 0 \\
\hline A. florida & 0 & 0 & 0 & 1 & 0 & 0 & 0 & 0 & 0 & 0 & 0 & 0 & 0 & 0 & 0 & 0 & 0 & 0 & 0 \\
\hline A. elseyi & 1 & 1 & 0 & 0 & 0 & 0 & 0 & 0 & 0 & 0 & 0 & 0 & 0 & 0 & 0 & 0 & 0 & 0 & 0 \\
\hline A. horrida & 1 & 1 & 0 & 0 & 0 & 0 & 0 & 0 & 0 & 0 & 0 & 0 & 0 & 0 & 0 & 0 & 0 & 0 & 0 \\
\hline A. echinata & 1 & 1 & 0 & 0 & 0 & 0 & 0 & 0 & 0 & 0 & 0 & 0 & 0 & 0 & 0 & 0 & 0 & 0 & 0 \\
\hline A. carduus & 1 & 0 & 1 & 0 & 0 & 0 & 0 & 0 & 0 & 0 & 0 & 0 & 0 & 0 & 0 & 0 & 0 & 0 & 0 \\
\hline A. clatbrata & 1 & 1 & 0 & 1 & 0 & 0 & 0 & 0 & 0 & 0 & 0 & 0 & 0 & 0 & 0 & 0 & 0 & 0 & 0 \\
\hline A. longicyatbus & 1 & 0 & 0 & 1 & 0 & 0 & 0 & 0 & 0 & 0 & 0 & 0 & 0 & 0 & 0 & 0 & 0 & 0 & 0 \\
\hline A. muricata & 1 & 1 & 1 & 1 & 0 & 0 & 0 & 0 & 0 & 0 & 0 & 0 & 0 & 0 & 0 & 0 & 0 & 0 & 0 \\
\hline A. retusa & 1 & 0 & 0 & 0 & 0 & 0 & 0 & 0 & 0 & 0 & 0 & 0 & 0 & 0 & 0 & 0 & 0 & 0 & 0 \\
\hline A. pulchra & 1 & 0 & 0 & 0 & 0 & 0 & 0 & 0 & 0 & 0 & 0 & 0 & 0 & 0 & 0 & 0 & 0 & 0 & 0 \\
\hline A. microphthalma & 1 & 1 & 1 & 1 & 0 & 0 & 0 & 0 & 0 & 0 & 0 & 0 & 0 & 0 & 0 & 0 & 0 & 0 & 0 \\
\hline A. intermedia & 1 & 0 & 1 & 1 & 0 & 0 & 0 & 0 & 0 & 0 & 0 & 0 & 0 & 0 & 0 & 0 & 0 & 0 & 0 \\
\hline A. austera & 1 & 0 & 0 & 0 & 0 & 0 & 0 & 0 & 0 & 0 & 0 & 0 & 0 & 0 & 0 & 0 & 0 & 0 & 0 \\
\hline A. tubicinaria & 1 & 0 & 0 & 1 & 0 & 0 & 0 & 0 & 0 & 0 & 0 & 0 & 0 & 0 & 0 & 0 & 0 & 0 & 0 \\
\hline A. tortuosa & 1 & 1 & 0 & 1 & 0 & 0 & 0 & 0 & 0 & 0 & 0 & 0 & 0 & 0 & 0 & 0 & 0 & 0 & 0 \\
\hline A. danai & 0 & 0 & 0 & 1 & 0 & 0 & 0 & 0 & 0 & 0 & 0 & 0 & 0 & 0 & 0 & 0 & 0 & 0 & 0 \\
\hline $\begin{array}{l}\text { Astreopora } \\
\quad \text { myriophthalma }\end{array}$ & 1 & 1 & 1 & 0 & 0 & 0 & 1 & 0 & 0 & 0 & 0 & 0 & 0 & 0 & 0 & 0 & 0 & 0 & 0 \\
\hline A. moretonensis & 0 & 0 & 0 & 0 & 0 & 0 & 1 & 0 & 0 & 0 & 0 & 0 & 0 & 0 & 0 & 0 & 0 & 0 & 0 \\
\hline Porites australiensis & 1 & 1 & 1 & 0 & 0 & 0 & 1 & 0 & 1 & 1 & 0 & 0 & 0 & 0 & 0 & 0 & 0 & 0 & 0 \\
\hline P. baueri & 0 & 0 & 0 & 0 & 0 & 0 & 0 & 1 & 0 & 0 & 0 & 0 & 0 & 0 & 0 & 0 & 0 & 0 & 0 \\
\hline P. lichen & 1 & 1 & 0 & 1 & 0 & 1 & 0 & 0 & 1 & 0 & 0 & 0 & 0 & 0 & 0 & 0 & 0 & 0 & 0 \\
\hline P. lobata & 1 & 1 & 1 & 1 & 1 & 1 & 1 & 1 & 1 & 1 & 1 & 1 & 1 & 1 & 1 & 1 & 1 & 1 & 1 \\
\hline P. lutea & 1 & 1 & 1 & 1 & 0 & 1 & 0 & 0 & 1 & 1 & 0 & 0 & 0 & 0 & 0 & 0 & 0 & 0 & 0 \\
\hline P. panamensis & 0 & 0 & 0 & 0 & 0 & 0 & 0 & 1 & 1 & 0 & 1 & 0 & 1 & 1 & 0 & 1 & 0 & 0 & 0 \\
\hline P. compressa & 0 & 0 & 0 & 0 & 0 & 1 & 0 & 0 & 0 & 0 & 0 & 0 & 0 & 0 & 0 & 0 & 0 & 0 & 0 \\
\hline P. duerdeni & 0 & 0 & 0 & 0 & 0 & 1 & 0 & 0 & 0 & 0 & 0 & 0 & 0 & 0 & 0 & 0 & 0 & 0 & 0 \\
\hline P. brighami & 0 & 0 & 0 & 0 & 0 & 1 & 0 & 0 & 0 & 0 & 0 & 0 & 0 & 0 & 0 & 0 & 0 & 0 & 0 \\
\hline P. pukoensis & 0 & 0 & 0 & 0 & 0 & 1 & 0 & 0 & 0 & 0 & 0 & 0 & 0 & 0 & 0 & 0 & 0 & 0 & 0 \\
\hline P. evermanni & 0 & 0 & 0 & 0 & 0 & 1 & 0 & 0 & 0 & 0 & 0 & 0 & 0 & 0 & 0 & 0 & 0 & 0 & 0 \\
\hline P. irregularis & 1 & 1 & 0 & 0 & 1 & 0 & 0 & 0 & 0 & 0 & 0 & 0 & 0 & 0 & 0 & 0 & 0 & 0 & 0 \\
\hline P. solida & 1 & 1 & 0 & 0 & 0 & 1 & 0 & 0 & 0 & 0 & 0 & 0 & 0 & 0 & 0 & 0 & 0 & 0 & 0 \\
\hline P. mordax & 0 & 1 & 0 & 0 & 0 & 0 & 0 & 0 & 0 & 0 & 0 & 0 & 0 & 0 & 0 & 0 & 0 & 0 & 0 \\
\hline P. convexa & 1 & 1 & 0 & 0 & 1 & 0 & 0 & 0 & 0 & 0 & 0 & 0 & 0 & 0 & 0 & 0 & 0 & 0 & 0 \\
\hline P.rus & 0 & 0 & 0 & 0 & 0 & 1 & 0 & 0 & 0 & 0 & 0 & 0 & 0 & 0 & 0 & 0 & 0 & 0 & 0 \\
\hline P. sverdrupi & 0 & 0 & 0 & 0 & 0 & 0 & 0 & 1 & 0 & 0 & 0 & 0 & 0 & 0 & 0 & 0 & 0 & 0 & 0 \\
\hline
\end{tabular}


Appendix 2 (continued)

\begin{tabular}{|c|c|c|c|c|c|c|c|c|c|c|c|c|c|c|c|c|c|c|c|}
\hline & SOC & TUA & GAM & AUS & MAR & HAW & PIT & MEM & REV & CLP & CRC & $\mathrm{COC}$ & PAN & COL & MAL & ECD & GAL & FAN & EAS \\
\hline P. arnaudi & 0 & 0 & 0 & 0 & 0 & 0 & 0 & 0 & 1 & 1 & 0 & 0 & 0 & 0 & 0 & 0 & 0 & 0 & 0 \\
\hline P. annae & 0 & 0 & 0 & 0 & 0 & 0 & 1 & 0 & 0 & 0 & 0 & 0 & 0 & 0 & 0 & 0 & 0 & 0 & 0 \\
\hline Alveopora verrilliana & 0 & 0 & 1 & 1 & 0 & 0 & 0 & 0 & 0 & 0 & 0 & 0 & 0 & 0 & 0 & 0 & 0 & 0 & 0 \\
\hline A. allingi & 0 & 0 & 1 & 1 & 0 & 0 & 0 & 0 & 0 & 0 & 0 & 0 & 0 & 0 & 0 & 0 & 0 & 0 & 0 \\
\hline Psammocora verrilli & 0 & 0 & 0 & 0 & 0 & 1 & 0 & 0 & 0 & 0 & 0 & 0 & 0 & 0 & 0 & 0 & 0 & 0 & 0 \\
\hline P. nierstraszi & 1 & 1 & 1 & 1 & 0 & 1 & 0 & 0 & 0 & 0 & 0 & 0 & 0 & 0 & 0 & 0 & 0 & 0 & 0 \\
\hline P. explanulata & 1 & 0 & 0 & 0 & 0 & 1 & 0 & 0 & 0 & 0 & 0 & 0 & 0 & 0 & 0 & 0 & 0 & 0 & 0 \\
\hline P. baimeana & 1 & 1 & 0 & 0 & 0 & 1 & 1 & 0 & 0 & 0 & 0 & 0 & 0 & 0 & 0 & 0 & 0 & 0 & 0 \\
\hline P. brighami & 0 & 0 & 0 & 0 & 0 & 0 & 0 & 1 & 0 & 0 & 1 & 0 & 1 & 1 & 0 & 1 & 1 & 0 & 0 \\
\hline P. obtusangula & 0 & 0 & 0 & 0 & 1 & 0 & 1 & 0 & 0 & 0 & 1 & 0 & 1 & 1 & 0 & 0 & 0 & 0 & 0 \\
\hline P. stellata & 0 & 0 & 0 & 0 & 0 & 1 & 0 & 1 & 1 & 1 & 1 & 1 & 1 & 1 & 0 & 1 & 1 & 0 & 1 \\
\hline P. superficialis & 1 & 1 & 0 & 0 & 0 & 1 & 0 & 1 & 1 & 1 & 1 & 1 & 1 & 1 & 0 & 1 & 1 & 0 & 0 \\
\hline P. digitata & 0 & 1 & 0 & 1 & 0 & 0 & 0 & 0 & 0 & 0 & 0 & 0 & 0 & 0 & 0 & 0 & 0 & 0 & 0 \\
\hline P. profundacella & 1 & 1 & 1 & 1 & 0 & 0 & 0 & 0 & 0 & 1 & 0 & 0 & 0 & 0 & 0 & 0 & 0 & 0 & 0 \\
\hline$P$. contigua & 1 & 1 & 1 & 1 & 0 & 0 & 0 & 0 & 0 & 0 & 0 & 0 & 0 & 0 & 0 & 0 & 0 & 0 & 0 \\
\hline Siderastrea glynni & 0 & 0 & 0 & 0 & 0 & 0 & 0 & 0 & 0 & 0 & 0 & 0 & 1 & 0 & 0 & 0 & 0 & 0 & 0 \\
\hline $\begin{array}{l}\text { Gardineroseris } \\
\text { planulata }\end{array}$ & 1 & 1 & 1 & 1 & 1 & 1 & 0 & 1 & 0 & 0 & 1 & 1 & 1 & 1 & 1 & 1 & 1 & 0 & 0 \\
\hline Leptoseris papyracea & 0 & 0 & 0 & 0 & 0 & 1 & 0 & 1 & 0 & 0 & 1 & 1 & 0 & 0 & 0 & 1 & 0 & 0 & 0 \\
\hline L. scabra & 1 & 0 & 0 & 1 & 0 & 1 & 0 & 0 & 0 & 1 & 1 & 1 & 0 & 0 & 0 & 0 & 1 & 0 & 1 \\
\hline L. tubulifera & 0 & 0 & 0 & 0 & 0 & 1 & 0 & 0 & 0 & 0 & 0 & 0 & 0 & 0 & 0 & 0 & 0 & 0 & 0 \\
\hline L. fragilis & 0 & 1 & 0 & 1 & 0 & 0 & 0 & 0 & 0 & 0 & 0 & 0 & 0 & 0 & 0 & 0 & 0 & 0 & 0 \\
\hline L. incrustans & 1 & 1 & 0 & 1 & 0 & 1 & 1 & 0 & 0 & 0 & 0 & 0 & 0 & 0 & 0 & 0 & 0 & 0 & 0 \\
\hline L. solida & 1 & 1 & 0 & 0 & 0 & 0 & 0 & 0 & 0 & 0 & 0 & 0 & 0 & 0 & 0 & 0 & 0 & 0 & 1 \\
\hline L. mycetoseroides & 1 & 1 & 0 & 1 & 0 & 1 & 0 & 0 & 0 & 0 & 0 & 0 & 0 & 0 & 0 & 0 & 0 & 0 & 0 \\
\hline L. hawaiiensis & 1 & 0 & 0 & 1 & 1 & 1 & 1 & 0 & 0 & 0 & 0 & 0 & 0 & 0 & 0 & 0 & 0 & 0 & 0 \\
\hline Pachyseris speciosa & 1 & 1 & 0 & 0 & 0 & 0 & 0 & 0 & 0 & 0 & 0 & 0 & 0 & 0 & 0 & 0 & 0 & 0 & 0 \\
\hline Pavona clavus & 1 & 1 & 1 & 1 & 0 & 0 & 0 & 1 & 1 & 1 & 1 & 1 & 1 & 1 & 1 & 1 & 1 & 1 & 0 \\
\hline P. frondifera & 0 & 0 & 0 & 0 & 0 & 0 & 0 & 0 & 0 & 0 & 1 & 0 & 1 & 1 & 0 & 0 & 0 & 0 & 0 \\
\hline P. gigantea & 0 & 0 & 0 & 0 & 0 & 0 & 0 & 1 & 1 & 1 & 1 & 1 & 1 & 1 & 0 & 1 & 1 & 1 & 0 \\
\hline P. maldivensis & 1 & 1 & 0 & 1 & 1 & 1 & 1 & 1 & 1 & 1 & 1 & 1 & 1 & 1 & 0 & 0 & 1 & 0 & 0 \\
\hline P. minuta & 0 & 1 & 0 & 1 & 0 & 0 & 0 & 1 & 1 & 1 & 0 & 0 & 0 & 0 & 0 & 0 & 0 & 0 & 0 \\
\hline P. varians & 1 & 1 & 1 & 1 & 1 & 1 & 1 & 1 & 1 & 1 & 1 & 1 & 1 & 1 & 1 & 1 & 1 & 1 & 0 \\
\hline P. xarifae & 0 & 0 & 0 & 0 & 0 & 0 & 0 & 0 & 0 & 0 & 0 & 1 & 0 & 0 & 0 & 0 & 0 & 0 & 0 \\
\hline P. chiriquiensis & 0 & 0 & 0 & 0 & 0 & 0 & 0 & 0 & 0 & 0 & 1 & 0 & 1 & 1 & 1 & 1 & 1 & 0 & 0 \\
\hline P. explanulata & 0 & 0 & 0 & 1 & 1 & 0 & 0 & 0 & 0 & 0 & 0 & 0 & 0 & 0 & 0 & 0 & 0 & 0 & 0 \\
\hline P. cactus & 1 & 0 & 0 & 0 & 0 & 0 & 0 & 0 & 0 & 0 & 0 & 0 & 0 & 0 & 0 & 0 & 0 & 0 & 0 \\
\hline P. duerdeni & 0 & 0 & 0 & 0 & 0 & 1 & 0 & 1 & 0 & 1 & 0 & 0 & 0 & 0 & 0 & 0 & 0 & 0 & 0 \\
\hline$P$. sp. 1 & 0 & 0 & 0 & 0 & 0 & 0 & 1 & 0 & 0 & 0 & 0 & 0 & 0 & 0 & 0 & 0 & 0 & 0 & 0 \\
\hline Fungia concinna & 1 & 1 & 0 & 0 & 1 & 0 & 0 & 0 & 0 & 0 & 0 & 0 & 0 & 0 & 0 & 0 & 0 & 0 & 0 \\
\hline F. distorta & 1 & 0 & 0 & 0 & 0 & 0 & 0 & 0 & 0 & 0 & 0 & 0 & 0 & 0 & 0 & 0 & 0 & 0 & 0 \\
\hline F. borrida & 1 & 0 & 1 & 0 & 0 & 0 & 0 & 0 & 0 & 0 & 0 & 0 & 0 & 0 & 0 & 0 & 0 & 0 & 0 \\
\hline F. paumotensis & 1 & 1 & 1 & 1 & 0 & 0 & 0 & 0 & 0 & 0 & 0 & 0 & 0 & 0 & 0 & 0 & 0 & 0 & 0 \\
\hline F. moluccensis & 1 & 0 & 0 & 0 & 0 & 0 & 0 & 0 & 0 & 0 & 0 & 0 & 0 & 0 & 0 & 0 & 0 & 0 & 0 \\
\hline F. granulosa & 0 & 1 & 0 & 1 & 0 & 1 & 0 & 0 & 0 & 0 & 0 & 0 & 0 & 0 & 0 & 0 & 0 & 0 & 0 \\
\hline F. repanda & 1 & 1 & 1 & 1 & 0 & 0 & 0 & 0 & 0 & 0 & 0 & 0 & 0 & 0 & 0 & 0 & 0 & 0 & 0 \\
\hline F. fungites & 1 & 0 & 0 & 0 & 0 & 0 & 0 & 0 & 0 & 0 & 0 & 0 & 0 & 0 & 0 & 0 & 0 & 0 & 0 \\
\hline F. scutaria & 1 & 1 & 1 & 1 & 0 & 1 & 1 & 0 & 0 & 0 & 0 & 0 & 0 & 0 & 0 & 0 & 0 & 0 & 0 \\
\hline Cycloseris curvata & 0 & 0 & 0 & 0 & 0 & 0 & 0 & 1 & 1 & 0 & 1 & 1 & 0 & 1 & 0 & 1 & 1 & 0 & 0 \\
\hline C. tenuis $=$ hexagonalis & 0 & 0 & 0 & 0 & 0 & 1 & 0 & 0 & 0 & 0 & 0 & 0 & 0 & 0 & 0 & 0 & 0 & 0 & 0 \\
\hline C. vaughani & 0 & 0 & 0 & 0 & 0 & 1 & 1 & 0 & 0 & 0 & 0 & 0 & 0 & 0 & 0 & 0 & 0 & 0 & 1 \\
\hline Sandalolitha dentata & 1 & 0 & 0 & 0 & 0 & 0 & 0 & 0 & 0 & 0 & 0 & 0 & 0 & 0 & 0 & 0 & 0 & 0 & 0 \\
\hline S. robusta & 1 & 1 & 1 & 0 & 0 & 0 & 0 & 0 & 0 & 0 & 0 & 0 & 0 & 0 & 0 & 0 & 0 & 0 & 0 \\
\hline Herpolitha limax & 1 & 1 & 1 & 1 & 0 & 0 & 0 & 0 & 0 & 0 & 0 & 0 & 0 & 0 & 0 & 0 & 0 & 0 & 0 \\
\hline $\begin{array}{l}\text { Diaseris distorta }= \\
\text { Cycloseris fragilis }\end{array}$ & 0 & 0 & 0 & 0 & 0 & 1 & 0 & 1 & 0 & 0 & 1 & 1 & 0 & 1 & 0 & 1 & 1 & 0 & 0 \\
\hline Cyphastrea serailia & 1 & 1 & 1 & 1 & 0 & 0 & 1 & 0 & 0 & 0 & 0 & 0 & 0 & 0 & 0 & 0 & 0 & 0 & 0 \\
\hline
\end{tabular}


Appendix 2 (continued)

\begin{tabular}{|c|c|c|c|c|c|c|c|c|c|c|c|c|c|c|c|c|c|c|c|}
\hline & soc & TUA & GAM & AUS & MAR & HAW & PIT & MEM & REV & CLP & CRC & $\mathrm{COC}$ & PAN & $\mathrm{COL}$ & MAL & ECD & GAL & FAN & EAS \\
\hline C. microphthalma & 1 & 0 & 0 & 1 & 0 & 0 & 0 & 0 & 0 & 0 & 0 & 0 & 0 & 0 & 0 & 0 & 0 & 0 & 0 \\
\hline C. ocellina & 0 & 0 & 0 & 0 & 0 & 1 & 0 & 0 & 0 & 0 & 0 & 0 & 0 & 0 & 0 & 0 & 0 & 0 & 0 \\
\hline Leptastrea bottae & 1 & 0 & 0 & 1 & 0 & 1 & 0 & 0 & 0 & 0 & 0 & 0 & 0 & 0 & 0 & 0 & 0 & 0 & 0 \\
\hline L. transversa & 1 & 1 & 0 & 1 & 0 & 0 & 1 & 0 & 0 & 0 & 0 & 0 & 0 & 0 & 0 & 0 & 0 & 0 & 1 \\
\hline L. purpurea & 1 & 1 & 1 & 1 & 0 & 1 & 1 & 0 & 0 & 0 & 0 & 0 & 0 & 0 & 0 & 0 & 0 & 0 & 1 \\
\hline Coscinarea columna & 0 & 0 & 1 & 1 & 0 & 0 & 0 & 0 & 0 & 0 & 0 & 0 & 0 & 0 & 0 & 0 & 0 & 0 & 0 \\
\hline C. wellsi & 0 & 0 & 0 & 1 & 0 & 1 & 0 & 0 & 0 & 0 & 0 & 0 & 0 & 0 & 0 & 0 & 0 & 0 & 0 \\
\hline Scolymia australiensis & 0 & 0 & 0 & 1 & 0 & 0 & 0 & 0 & 0 & 0 & 0 & 0 & 0 & 0 & 0 & 0 & 0 & 0 & 0 \\
\hline S. vitiensis & 0 & 0 & 0 & 1 & 0 & 0 & 1 & 0 & 0 & 0 & 0 & 0 & 0 & 0 & 0 & 0 & 0 & 0 & 0 \\
\hline Lobopbyllia bemprichi & 1 & 1 & 0 & 0 & 0 & 0 & 0 & 0 & 0 & 0 & 0 & 0 & 0 & 0 & 0 & 0 & 0 & 0 & 0 \\
\hline L. costata & 1 & 1 & 1 & 0 & 0 & 0 & 0 & 0 & 0 & 0 & 0 & 0 & 0 & 0 & 0 & 0 & 0 & 0 & 0 \\
\hline L. corymbosa & 0 & 1 & 0 & 1 & 0 & 0 & 0 & 0 & 0 & 0 & 0 & 0 & 0 & 0 & 0 & 0 & 0 & 0 & 0 \\
\hline Acanthastrea echinata & 1 & 1 & 1 & 1 & 0 & 0 & 0 & 0 & 0 & 0 & 0 & 0 & 0 & 0 & 0 & 0 & 0 & 0 & 0 \\
\hline Echinophyllia aspera & 1 & 1 & 1 & 1 & 0 & 0 & 0 & 0 & 0 & 0 & 0 & 0 & 0 & 0 & 0 & 0 & 0 & 0 & 0 \\
\hline E. echinata & 0 & 0 & 0 & 1 & 0 & 0 & 0 & 0 & 0 & 0 & 0 & 0 & 0 & 0 & 0 & 0 & 0 & 0 & 0 \\
\hline Caulastrea furcata & 0 & 0 & 0 & 0 & 0 & 0 & 1 & 0 & 0 & 0 & 0 & 0 & 0 & 0 & 0 & 0 & 0 & 0 & 0 \\
\hline Favia pallida & 0 & 1 & 0 & 1 & 0 & 0 & 0 & 0 & 0 & 0 & 0 & 0 & 0 & 0 & 0 & 0 & 0 & 0 & 0 \\
\hline F. favus & 0 & 1 & 1 & 1 & 0 & 0 & 0 & 0 & 0 & 0 & 0 & 0 & 0 & 0 & 0 & 0 & 0 & 0 & 0 \\
\hline F. matthaii & 0 & 0 & 0 & 0 & 0 & 0 & 1 & 0 & 0 & 0 & 0 & 0 & 0 & 0 & 0 & 0 & 0 & 0 & 0 \\
\hline F. rotumana & 0 & 1 & 0 & 1 & 0 & 0 & 1 & 0 & 0 & 0 & 0 & 0 & 0 & 0 & 0 & 0 & 0 & 0 & 0 \\
\hline F. amicorum & 0 & 0 & 0 & 1 & 0 & 0 & 0 & 0 & 0 & 0 & 0 & 0 & 0 & 0 & 0 & 0 & 0 & 0 & 0 \\
\hline F. speciosa & 0 & 1 & 1 & 0 & 0 & 0 & 0 & 0 & 0 & 0 & 0 & 0 & 0 & 0 & 0 & 0 & 0 & 0 & 0 \\
\hline F. stelligera & 1 & 1 & 1 & 0 & 0 & 0 & 1 & 0 & 0 & 0 & 0 & 0 & 0 & 0 & 0 & 0 & 0 & 0 & 0 \\
\hline Favites flexuosa & 0 & 0 & 0 & 1 & 0 & 0 & 0 & 0 & 0 & 0 & 0 & 0 & 0 & 0 & 0 & 0 & 0 & 0 & 0 \\
\hline F. complanata & 1 & 1 & 0 & 0 & 0 & 0 & 0 & 0 & 0 & 0 & 0 & 0 & 0 & 0 & 0 & 0 & 0 & 0 & 0 \\
\hline F. abdita & 1 & 0 & 0 & 0 & 0 & 0 & 0 & 0 & 0 & 0 & 0 & 0 & 0 & 0 & 0 & 0 & 0 & 0 & 0 \\
\hline F. russeli & 0 & 0 & 0 & 1 & 0 & 0 & 0 & 0 & 0 & 0 & 0 & 0 & 0 & 0 & 0 & 0 & 0 & 0 & 0 \\
\hline Goniastrea pectinata & 0 & 0 & 0 & 1 & 0 & 0 & 0 & 0 & 0 & 0 & 0 & 0 & 0 & 0 & 0 & 0 & 0 & 0 & 0 \\
\hline G. australiensis & 0 & 0 & 0 & 1 & 0 & 0 & 1 & 0 & 0 & 0 & 0 & 0 & 0 & 0 & 0 & 0 & 0 & 0 & 0 \\
\hline Bikiniastrea laddi & 0 & 1 & 0 & 1 & 0 & 0 & 0 & 0 & 0 & 0 & 0 & 0 & 0 & 0 & 0 & 0 & 0 & 0 & 0 \\
\hline Montastrea curta & 1 & 1 & 1 & 1 & 0 & 0 & 1 & 0 & 0 & 0 & 0 & 0 & 0 & 0 & 0 & 0 & 0 & 0 & 0 \\
\hline Plesiastrea versipora & 1 & 0 & 0 & 0 & 0 & 0 & 1 & 0 & 0 & 0 & 0 & 0 & 0 & 0 & 0 & 0 & 0 & 0 & 0 \\
\hline Platygyra daedalea & 1 & 1 & 0 & 1 & 0 & 0 & 0 & 0 & 0 & 0 & 0 & 0 & 0 & 0 & 0 & 0 & 0 & 0 & 0 \\
\hline P. pini & 0 & 0 & 0 & 1 & 0 & 0 & 0 & 0 & 0 & 0 & 0 & 0 & 0 & 0 & 0 & 0 & 0 & 0 & 0 \\
\hline Leptoria phrygia & 0 & 0 & 1 & 1 & 0 & 0 & 0 & 0 & 0 & 0 & 0 & 0 & 0 & 0 & 0 & 0 & 0 & 0 & 0 \\
\hline Merulina ampliata & 0 & 0 & 0 & 1 & 0 & 0 & 0 & 0 & 0 & 0 & 0 & 0 & 0 & 0 & 0 & 0 & 0 & 0 & 0 \\
\hline Madracis kirbyi & 0 & 1 & 0 & 1 & 0 & 0 & 0 & 0 & 0 & 0 & 0 & 0 & 0 & 0 & 0 & 0 & 0 & 0 & 0 \\
\hline $\begin{array}{c}\text { Hydnophora } \\
\text { microconos }\end{array}$ & 0 & 0 & 0 & 1 & 0 & 0 & 0 & 0 & 0 & 0 & 0 & 0 & 0 & 0 & 0 & 0 & 0 & 0 & 0 \\
\hline Echinopora geтmасеа & 0 & 0 & 0 & 1 & 0 & 0 & 0 & 0 & 0 & 0 & 0 & 0 & 0 & 0 & 0 & 0 & 0 & 0 & 0 \\
\hline E. lamellosa & 1 & 1 & 0 & 1 & 0 & 0 & 0 & 0 & 0 & 0 & 0 & 0 & 0 & 0 & 0 & 0 & 0 & 0 & 0 \\
\hline Galaxea fascicularis & 1 & 0 & 0 & 1 & 0 & 0 & 0 & 0 & 0 & 0 & 0 & 0 & 0 & 0 & 0 & 0 & 0 & 0 & 0 \\
\hline $\begin{array}{l}\text { Mycedium } \\
\text { elephantotus }\end{array}$ & 1 & 0 & 1 & 0 & 0 & 0 & 0 & 0 & 0 & 0 & 0 & 0 & 0 & 0 & 0 & 0 & 0 & 0 & 0 \\
\hline $\begin{array}{l}\text { Turbinaria } \\
\quad \text { mesenterina }\end{array}$ & 0 & 0 & 0 & 1 & 0 & 0 & 0 & 0 & 0 & 0 & 0 & 0 & 0 & 0 & 0 & 0 & 0 & 0 & 0 \\
\hline
\end{tabular}

Note: Species entries for French Polynesia (SOC, Society Islands; TUA, Tuamotus; GAM, Gambiers; AUS, Australs; MAR, Marquesas) are from M. Pichon (2005, unpubl. records). HAW, Hawaiian Islands; PIT, Pitcairn Island; MEM, Mexican mainland; REV, Revillagigedo Islands, Mexico; CLP, Clipperton Atoll; CRC, Costa Rica; COC, Cocos Island, Costa Rica; PAN, Panamá; COL, Colombia; MAL, Malpelo Island; ECD, Ecuadorean coast; GAL, Galápagos Islands; FAN, Fanning Atoll (= Tabuaeran); EAS, Easter Island (= Rapa Nui). 